Archaeologia Historica Polona tom 26, 2018, ISSN 1425-3534

Instytut Archeologii

http://dx.doi.org/10.12775/AHP.2018.017

Uniwersytet Jagielloński

MICHAL WOJENKA

\title{
Najnowsze badania archeologiczne budownictwa obronnego na Jurze Ojcowskiej
}

\section{Recent archaeological research on defensive architecture in the Ojców Jura}

Zarys treści. Artykuł zawiera informacje o wynikach badań archeologicznych zrealizowanych w latach 2015-2017 na czterech obiektach obronnych położonych na terenie Jury Ojcowskiej. Zaprezentowano rezultaty prac przeprowadzonych w Grodzisku koło Skały, w którym część badaczy lokalizuje warowny klasztor klarysek z 2. połowy XIII wieku, a także na zamku w Ojcowie (w rejonie wieży ośmiobocznej). Przedstawiono też wyniki badań dwóch małych założeń obronnych - w Jerzmanowicach i Dubiu.

Slowa kluczowe: Wyżyna Krakowsko-Częstochowska, Jura Ojcowska, średniowiecze, zamki, grodziska, Grodzisko koło Skały, Jerzmanowice, Dubie, Ojców.

\section{Uwagi wstępne}

„W odległości dwóch mil od Krakowa, w północno-zachodniey stronie, leżą wdzięczne Oycowa, Grodziska i Pieskowey Skały okolice, słusznie Szwaycaryą polską zwane. Natura w cudach niewyczerpana, mieyscom tem hoynie udzieliła piękności" - pisał w początku XIX stulecia Ambroży Grabowski, jeden z najwybitniejszych przedstawicieli najstarszego pokolenia polskich starożytników (Grabowski 1822, s. 200). Opis ten odnosi się do Doliny Prądnika, stanowiącej główną oś tak zwanej Jury Ojcowskiej, obszaru położonego w południowej części Wyżyny Krakowsko-Częstochowskiej (Jura Ojcowska w pradziejach 2006). Ten wyżynny obszar odznacza się łagodnie pofalowaną wierzchowiną, miejscami urozmaiconą ostańcami wapiennymi o genezie górnojurajskiej, rozciętą jarowymi dolinami potoków Prądnika, Sąspówki, Szklarki, Racławki i Będkówki (Kondracki 1998, s. 255). Czynnikiem decydującym o wyjątkowym krajobrazie dolin są 
występujące na ich stokach liczne formy skalne, niekiedy osiągające kilkadziesiąt metrów wysokości. Nierzadko mieszczą one jaskinie i mniejsze schroniska skalne (Gradziński, Gradziński, Jach 2008, s. 56-66).

Dla archeologów i historyków średniowiecza Jura Ojcowska stanowi bardzo atrakcyjny obszar badawczy. Znajdują się tu liczne osady wiejskie o metryce sięgającej w głąb wieków średnich (Kiryk 1978; Laberschek 1995; 2016), jaskinie przechowujące rozmaite ślady średniowiecznej aktywności człowieka (Wojenka 2012; 2018), przede wszystkim zaś przykłady dawnego budownictwa obronnego, występujące tu zarówno w postaci grodzisk, jak i murowanych zamków (Kołodziejski 2006; 2016). Przykłady tych ostatnich - Pieskowa Skała lub Ojców - na trwałe wpisały się w zbiorową świadomość kolejnych pokoleń Polaków.

$\mathrm{W}$ niniejszym artykule zaprezentuję wstępne wyniki najnowszych badań archeologicznych, które przeprowadziłem w latach 2015-2017 na czterech różnych obiektach obronnych położonych na Jurze Ojcowskiej: w Grodzisku koło Skały, Jerzmanowicach-Starej Wsi, Dubiu oraz na zamku w Ojcowie (ryc. 1). Nie licząc warowni w Jerzmanowicach, która doczekała się osobnej publikacji (Wojenka 2016a), wyniki badań na pozostałych obiektach nie były dotąd publikowane.

\section{Grodzisko koło Skaty}

W studiach nad średniowiecznym krajobrazem osadniczym dawnej ziemi krakowskiej mało jest zagadnień równie kontrowersyjnych, jak przeszłość zespołu tzw. Pustelni błogosławionej Salomei w Grodzisku koło Skały, położonej na skalnym cyplu na lewym brzegu Prądnika (ryc. 1,2). Na pierwszy rzut oka wydaje się on wyłącznie barokową realizacją sakralną o bogatym programie ideowym. Ów wykreowany przez księdza Sebastiana Piskorskiego w ostatniej ćwierci XVII wieku zespół składa się z kościoła filialnego pw. Wniebowzięcia NMP, kilku pustelniczych grot - kaplic, właściwego budynku tzw. Pustelni błogosławionej Salomei oraz ceglanego domu kapelana (Dreścik 1987; Holcerowa 2007; Kurzej 2014). Przestrzeń wokół świątyni obwiedziona jest kamiennym murem, wyznaczającym zasięg przykościelnego cmentarza (ryc. 3). Między nowożytnymi elementami zabudowy kompleksu widnieją jednak pozostałości wcześniejszej historii tego miejsca, w dużej mierze odnoszące się do średniowiecza. Między innymi są to pozostałości murów z kamieni wapiennych, w tym czytelne jeszcze do niedawna pozostałości starszej budowli tkwiące w bryle późnobarokowej świątyni, w szczególności zaś potężny wał obronny, który wraz z suchą fosą odcina cypel od reszty wysoczyzny (ryc. 2).

$\mathrm{Z}$ uwagi na bardzo słaby stan archeologicznego rozpoznania zespołu nie dysponujemy, jak dotąd, wiedzą o jego układzie przestrzennym w okresie poprzedzającym realizację barokową. Dotychczasowe prace archeologiczno-architektoniczne ograniczały się do badań Władysława Grabskiego i Wiktora 


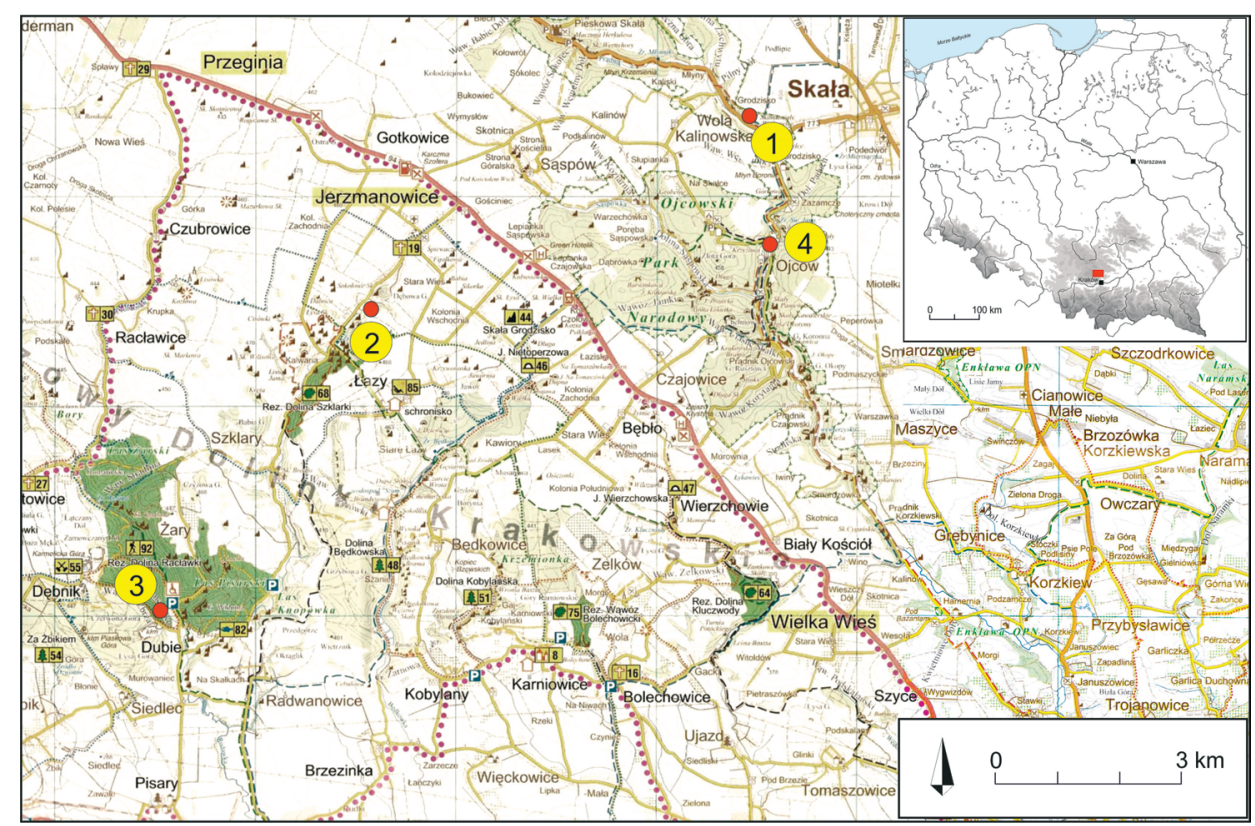

Ryc. 1. Okolice Ojcowa z uwzględnieniem obiektów obronnych badanych w latach 2015-2017: 1 - Grodzisko, koło Skały; 2 - Jerzmanowice-Stara Wieś; 3 - Dubie; 4 - Ojców (oprac. M. Wojenka)

Fig. 1. Area of Ojcow including defensive structures studied in 2015-2017: 1 - Grodzisko koło Skały; 2 - Jerzmanowice-Stara Wieś; 3 - Dubie; 4 - Ojców (edited by M. Wojenka)

Zina przeprowadzonych w rejonie kościoła w latach 1961-1963 i 1967-1968, prac Andrzeja Żakiego (1962 rok) oraz eksploracji podejmowanych w różnych partiach obiektu przez Stanisława Kołodziejskiego (1996 rok), Zygmunta Holcera i Waldemara Niewaldę (lata 1999-2001) oraz Witolda Domogallę i Sławomira Dryję (2003 rok).

O wynikach badań przeprowadzonych w latach 60. XX wieku właściwie niewiele wiadomo. Z krótkiego komunikatu, stanowiącego w zasadzie jedyny publikowany ich ślad ${ }^{1}$, wynika, że na znacznej powierzchni odsłonięto fundament świątyni. Jego plan W. Zin i W. Grabski uznali za „nie spotykany w architekturze polskiej" i znacznie starszy od świątyni XVII-wiecznej, wiążąc go z okresem wczesnośredniowiecznym (Zin, Grabski 1970, s. 336). Datowanie tej starszej budowli A. Żaki oceniał na wiek XIII (Żaki 1974, s. 408, przypis 139).

Nieco więcej danych dostarczyły badania prowadzone w końcu XX i na początku obecnego stulecia, które, niestety, dotąd nie doczekały się publikacji.

${ }^{1}$ Rezultaty przeprowadzonych wówczas w Grodzisku prac wykopaliskowych zostały upowszechnione $\mathrm{w}$ doniesieniach prasowych oraz w popularnonaukowym opracowaniu pióra Jana Adamczewskiego (1968, s. 144-146). 


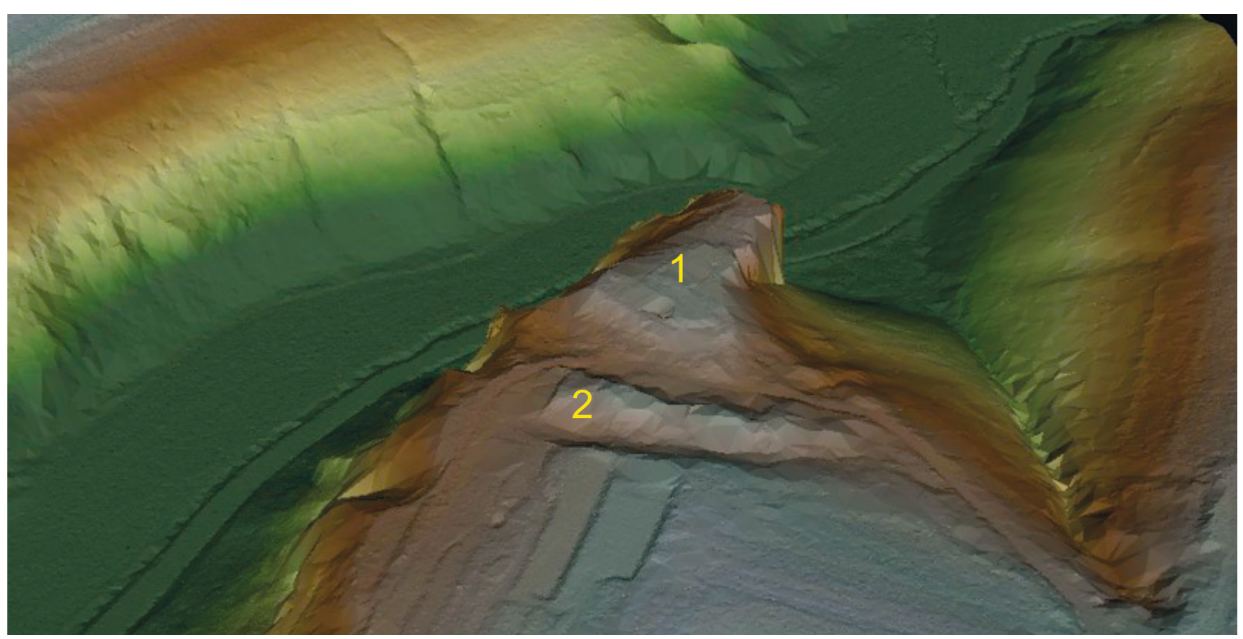

Ryc. 2. Grodzisko koło Skały. Zdjęcie z lotniczego skaningu laserowego (LiDAR) - widok od wschodu: 1 - główna część założenia, zawierająca między innymi kościół, dom kapelana i kaplice; 2 - wał obronny (z archiwum Ojcowskiego Parku Narodowego)

Fig. 2. Grodzisko koło Skały. Photo from aerial laser scanning (LiDAR) - view from the east: 1 - main part of the complex, containing, among others, church, chaplain's house and chapels; 2 - defensive rampart (from the archives of the Ojców National Park)

W kilku miejscach wprawdzie odsłonięto średniowieczne mury, jednak z uwagi na niewielki zakres prac, ich autorom nie udało się uzyskać danych pozwalających na nie budzącą wątpliwości rekonstrukcję rozplanowania badanych części pierwotnego zespołu (Domogalla 2005, s. 108-157). Pozyskane wówczas ruchome materiały źródłowe datowano na 2. połowę XIII i początek XIV stulecia (Kołodziejski 2016, s. $72^{2}$ ).

Z rezultatów wcześniejszych prac archeologiczno-architektonicznych wyłania się niełatwy do interpretacji obraz Grodziska jako miejsca znacznie nasyconego bardzo słabo rozpoznanymi i trudnymi do określenia reliktami murów kamiennych, które przechowane są głównie pod barokową zabudową i poniżej współczesnego poziomu gruntu (Domogalla 2005; Domogalla, Mościcki 2006). Trudności w interpretacji wyników prowadzonych tam badań potęguje znikomy stan publikacji. Nie licząc maszynopisów (w tym cennej rozprawy doktorskiej W. Domogalli) oraz zdawkowej relacji W. Zina i W. Grabskiego, w zasadzie jedynymi publikowanymi punktami odniesienia dla reliktów starszej zabudowy murowanej pozostają opracowania Z. Holcera (Holcer 2001, s. 359) oraz W. Domogalli i W. Mościckiego, to

2 Tam odniesienia do maszynopisów sprawozdań z badań wykopaliskowych, przechowywanych w Archiwum Małopolskiego Wojewódzkiego Konserwatora Zabytków w Krakowie. Należy dodać, że z badań przeprowadzonych w 2003 roku pochodzi unikatowe znalezisko - średniowieczna zapinka lub okucie księgi w kształcie dłoni, zdobione rytym ornamentem (Domogalla 2006, s. 355-357). 


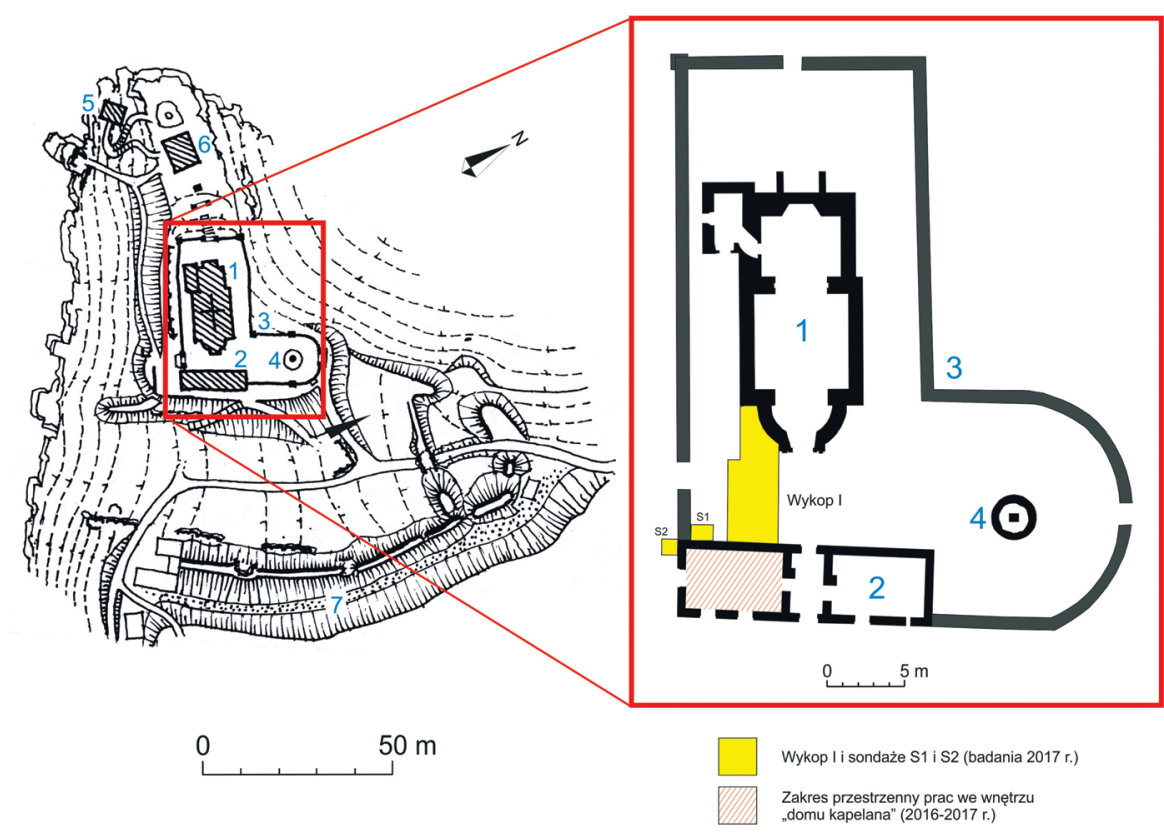

Ryc. 3. Grodzisko koło Skały. Plan zespołu architektoniczno-przestrzennego z zaznaczeniem miejsca badań przeprowadzonych w latach 2016-2017: 1 - kościół pw. Wniebowzięcia NMP (średniowiecze?, XVII wiek); 2 - tzw. dom kapelana (XVII wiek); 3 - mur kamienny (XVII wiek); 4 - figura św. Klary (XVII i XX wiek); 5, 6 - kaplice (XVII wiek); 7 - wał obronny (średniowiecze?) (wg Bogdanowski 1993; oprac. M. Wojenka)

Fig. 3. Grodzisko koło Skały. Plan of the architectural and spatial complex with marking of the place of research carried out in 2016-2017: 1 - the Assumption of the Virgin Mary's church (Middle Ages?, 17 $7^{\text {th }}$ century); 2 - so-called chaplain's house ( $17^{\text {th }}$ century $) ; 3$ - stone wall $\left(17^{\text {th }}\right.$ century $) ; 4$ - figure of St Clare $\left(17^{\text {th }}\right.$ and $20^{\text {th }}$ century); 5,6 - chapels ( $17^{\text {th }}$ century); 7 - defensive rampart (Middle Ages?) (after Bogdanowski 1993; edited by M. Wojenka)

ostatnie poświęcone jednak głównie wynikom badań geofizycznych (Domogalla, Mościcki 2006).

W latach 2016-2017 na terenie zespołu architektoniczno-przestrzennego w Grodzisku wznowiono prace archeologiczne. Przeprowadzono je w dwóch miejscach stanowiska - w południowej części domu kapelana oraz pomiędzy nim a wschodnią częścią kościoła, w obrębie murów dawnego cmentarza (ryc. 3). Dobór miejsca podyktowany był z jednej strony koniecznością rozpoznania sposobu posadowienia murów budynku w celu podjęcia w nim działań naprawczych, z drugiej zaś wiązał się z nadzieją na uchwycenie relacji stratygraficznych między fundamentem świątyni a murami ukrytych pod domem kapelana piwnic, znanych już dzięki ustaleniom W. Domogalli oraz Z. Holcera. 
Prace prowadzone w obrębie budynku miały niewielki zakres i ograniczały się do odsłonięcia górnej partii sklepienia znajdujących się pod nim kamiennych piwnic (ryc. 4: A). Odłożyła się na nim kilkunastocentymetrowej miąższości warstwa nasypu, zawierającego głównie materiały późnonowożytne, choć wystąpiły tam również pojedyncze znaleziska średniowieczne, zalegające na wtórnym złożu. Sklepienie wykonano z wapiennych kamieni przełożonych zaprawą gliniano-wapienną. Niestety, jego dokładnych granic nie udało się uchwycić w obrębie pomieszczenia. Część wschodnia okazała się w dużej mierze zniszczona, natomiast $\mathrm{z}$ badań prowadzonych na zewnątrz domu kapelana wynika, że od zachodu mur piwnic przebiegał pod murem budynku barokowego. O grubości sklepienia trudno się wypowiadać; wynosi ona przynajmniej $70 \mathrm{~cm}$, na co wskazują obserwacje poczynione w południowo-wschodniej partii pomieszczenia, w której jego część rozkuto dla uzyskania miejsca na ceglaną czeluść pieca kaflowego. Jak wskazują znalezione tam kafle z charakterystyczną pobiałą i wypukłymi żeberkami, prace te miały miejsce u schyłku XVIII wieku (Moskal 2012, s. 399).

Zdecydowanie więcej danych dostarczyły badania przeprowadzone na zewnątrz domu kapelana. Między nim a wschodnią partią świątyni założono wykop główny (I). Dwa małe sondaże (S1 i S2) umieszczono w południowo-zachodnim narożniku budynku, kierując się potrzebami inwestorskimi ${ }^{3}$ (ryc. 3).

Wykop główny (I), w założeniach miał na celu rozpoznanie uwarstwienia badanej części zespołu, ustalenie relacji stratygraficznych między fundamentem kościoła a murami piwnic pod domem kapelana ${ }^{4}$ oraz sposobu posadowienia tych fundamentów, wreszcie datowanie zachowanych reliktów murowanych. Prace prowadzono do osiągnięcia stóp fundamentowych świątyni i piwnic (ryc. 5).

Wierzchnią partię osadów w wykopie I stanowiły nasypy o późnej metryce (warstwy 1-4), przecięte kilkoma wkopami instalacyjnymi (warstwa 2a-c) lub naprawczymi (warstwa 5). Wystąpił w nich przede wszystkim materiał nowożytny, w tym kilkanaście drobnych monet, głównie szelągów miedzianych Jana Kazimierza z 2. połowy XVII wieku. Mając na uwadze fakt, że wykop I wytyczono tuż przed wejściem do świątyni, wymienione znaleziska najpewniej były zagubionymi datkami wiernych. $Z$ fazą nowożytną wiąże się też dość głęboki wkop (warstwa $6^{5}$ ) o płaskim dnie, który zajmował cały południowo-wschodni narożnik wykopu. W partii dennej zawierał on resztki drewnianego koryta wypełnionego rozlasowanym wapnem, które na zewnątrz uszczelniono kilkoma warstwami szarozielonego iłu. Można interpretować go jako dół do gaszenia wapna, związany z placem budowy z lat 1677-1691, a zatem z późnobarokową

\footnotetext{
${ }^{3}$ Doprowadzono je do niewielkiej głębokości, nieprzekraczającej poziomu nasypów nowożytnych.

${ }^{4}$ Przed rozpoczęciem badań zakładano jednak, że w związku ze znacznym zakresem badań architektoniczno-archeologicznych W. Zina i W. Grabskiego, relacji tych najpewniej nie uda się określić.

${ }^{5}$ Wkop ten nie jest widoczny na dołączonym do niniejszej pracy rysunku przekroju północnego wykopu I.
} 

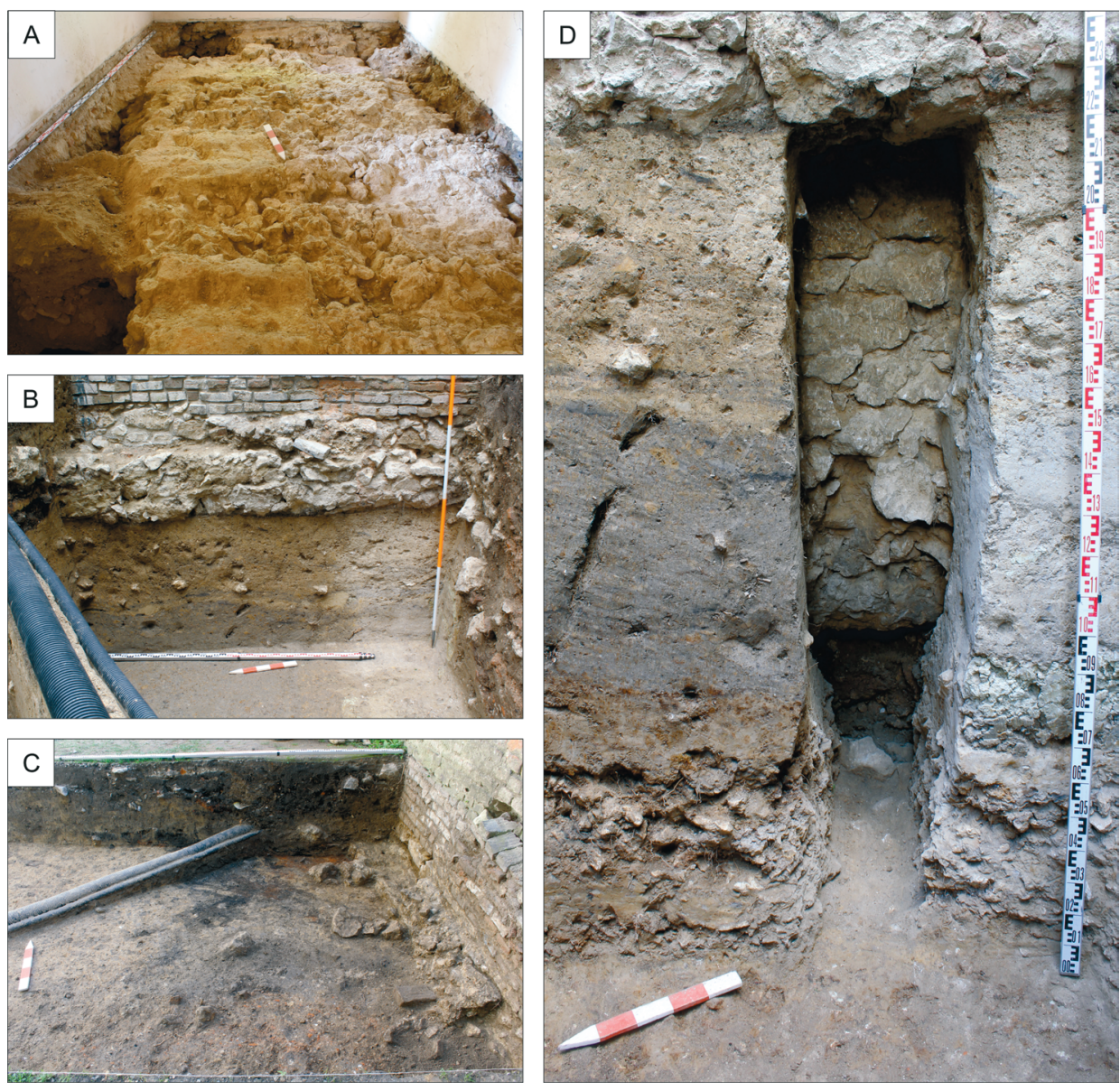

Ryc. 4. Grodzisko koło Skały. A - sklepienie piwnic w pomieszczeniu południowym domu kapelana; B - kamienny fundament domniemanego budynku średniowiecznego; C - warstwa destrukcyjna (warstwa 7) ze śladami po zabudowie średniowiecznej; D - mur piwnic pod budynkiem domu kapelana (fot. M. Wojenka)

Fig. 4. Grodzisko koło Skały. A - vault of cellars in the southern room of the chaplain's house; $\mathrm{B}$ - stone foundation of the alleged medieval building; $\mathrm{C}$-destruction layer (layer 7) with traces of medieval buildings; D - cellars wall under the building of the chaplain's house (photo by M. Wojenka)

realizacją księdza Sebastiana Piskorskiego. Przemawia za tym znalezienie w wypełnisku wkopu dwóch szelągów miedzianych Jana Kazimierza, w tym jednego w warstwie uszczelniającego iłu ${ }^{6}$.

\footnotetext{
${ }^{6}$ Szelągi miedziane Jana Kazimierza, tzw. boratynki, bito w Koronie od 1659 roku, na Litwie zaś od 1660 roku (Wnęk 2013, s. 171). Egzemplarz z warstwy iłu ma zatartą datę emisji, drugi z okazów wybito w roku 1661.
} 


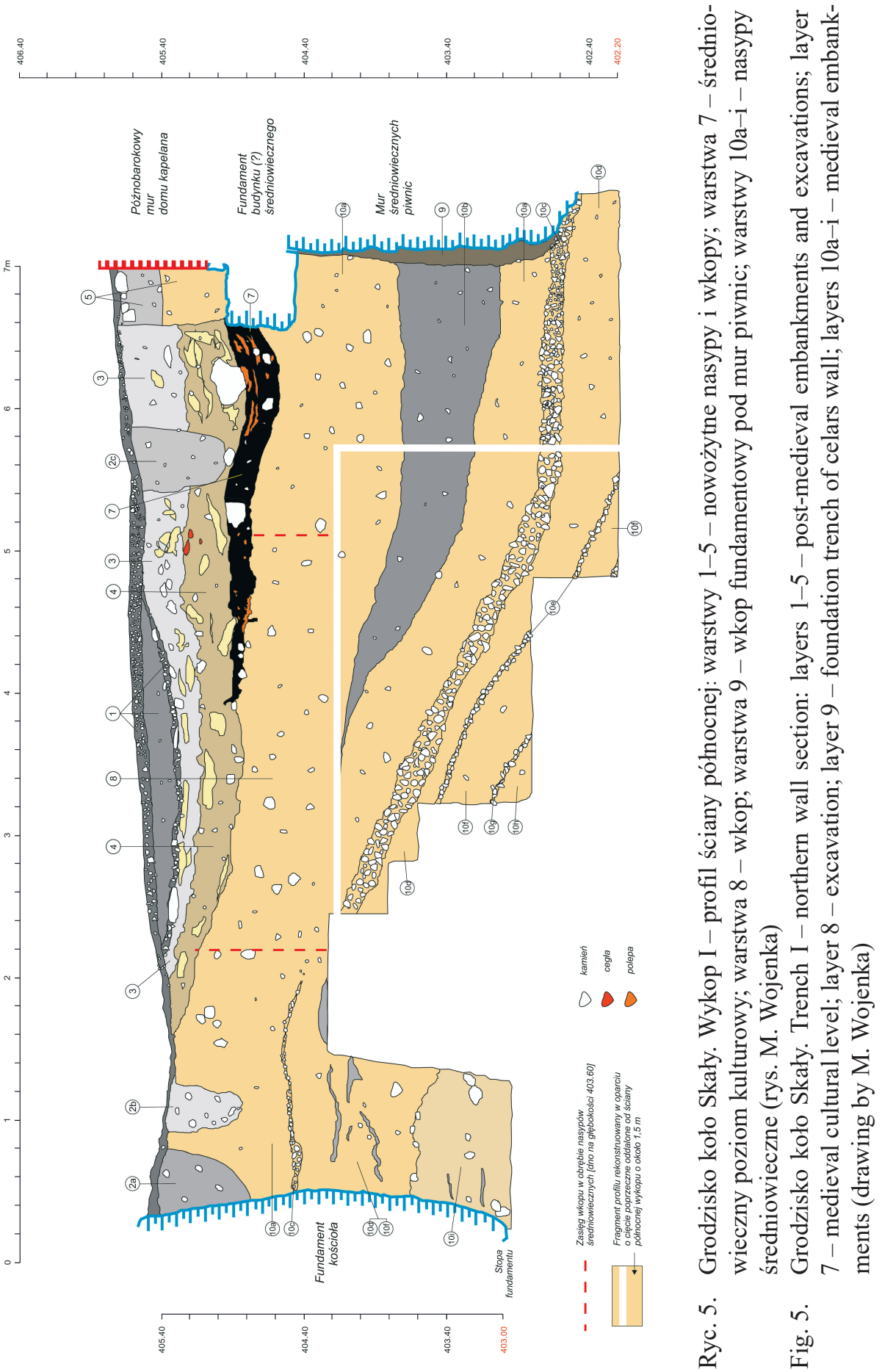


W zachodniej partii wykopu, tuż przy fundamencie świątyni, na głębokości około $70 \mathrm{~cm}$ zarysowała się jama grobowa o wymiarach $40 \times$ około $180 \mathrm{~cm}^{7}$, której północna część była zbliżona do półkola. Zalegały w niej szczątki kobiety w wieku iuvenis (18-20 lat) o przeżyciowej wysokości ciała około $165 \mathrm{~cm}^{8}$. Pochówek zorientowany był wzdłuż osi północny wschód-południowy zachód, z czaszką na północny wschód, tj. w kierunku wejścia do świątyni. Jedynym elementem wyposażenia zmarłej był brązowy krzyżyk, odnaleziony na wysokości jej szyi. Nieco powyżej kolan znajdowały się słabo zachowane szczątki dziecka w wieku infans I (1-2 lata). Niewielka szerokość jamy grobowej i brak śladów trumny wskazują, że obie osoby - zapewne matkę z dzieckiem - złożono do grobu owinięte całunem. Pochówek na podstawie krzyżyka należy odnieść do końca XVII i całego XVIII stulecia. Odkrycie grobu w sposób jednoznaczny wskazuje, że teren przy murze kościelnym przynajmniej w badanej części stanowiska nie został poważnie naruszony wykopami W. Zina i W. Grabskiego.

We wschodniej partii wykopu, poniżej nawarstwień nowożytnych zalegał ciemnoszaro-czarny utwór o miąższości 15-35 cm (warstwa 7; ryc. 4: C), który zawierał bardzo wyraźne ślady spalenizny, kamienie wapienne oraz liczne kęsy polepy, w tym również z odciskami konstrukcji. Warstwa ta wyznacza poziom destrukcji bliżej nieokreślonej budowli, której fundament być może stanowił dość płytko posadowiony $(50 \mathrm{~cm})$ i niezbyt szeroki (około $55 \mathrm{~cm}$ ) mur wapienny, odsłonięty bezpośrednio przy murze domu kapelana (ryc. 4: B, ryc. 5). Z obserwacji stratygraficznych wynika, że warstwa 7 raczej nie została przecięta wspomnianym murem, za czym przemawiają laminy polepy, ,zawijające się” na jego koronę (ryc. 5).

Niewielki zakres przestrzenny prac nie pozwala na wiarygodną interpretację opisywanego reliktu. Mając na uwadze niewielkie jego rozmiary i płytkość posadowienia wydaje się jednak, że jeśli w ogóle pełnił on funkcję podwaliny, to musiał to być budynek o lekkiej, na przykład szachulcowej konstrukcji. Przemawiają za tym wspomniane wyżej znaleziska polepy. Uzyskana dla warstwy 7 data radiowęglowa $(725 \pm 30 \mathrm{BP})^{9}$ wskazuje, że zniszczenie obiektu nastąpiło w 2. połowie XIII lub na początku XIV stulecia.

Interesująco przedstawiają się znaleziska z warstwy 7. Prócz licznych ułamków naczyń ceramicznych (ryc. 6), natrafiono w niej między innymi na pięć żelaznych grotów bełtów, zgrzebło do końskiego włosia oraz żelazną ostrogę z bodźcem

\footnotetext{
${ }^{7}$ Południowy skraj jamy grobowej wychodził poza obręb wykopu, stąd jej długość określono jedynie orientacyjnie.

${ }^{8}$ Ekspertyzę antropologiczną zawdzięczam dr hab. Anicie Szczepanek z Katedry i Zakładu Anatomii Collegium Medicum Uniwersytetu Jagiellońskiego, której składam w tym miejscu serdeczne podziękowania.

${ }^{9}$ Datowania wykonano w Poznańskim Laboratorium Radiowęglowym na próbie pochodzącej z węgla drzewnego (Poz-96843); OxCal: 68,2\% - 1265 AD (68,2\%), 1288 AD; 95,4\% - 1225 AD $(1,6 \%), 1233 \mathrm{AD}, 1243 \mathrm{AD}(91,3 \%), 1300 \mathrm{AD}, 1370 \mathrm{AD}(2,5 \%) 1380 \mathrm{AD}$.
} 


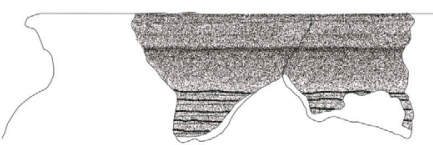

1

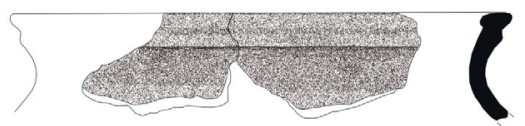

3



5

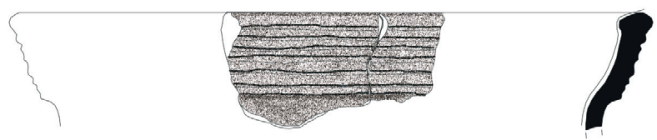

7

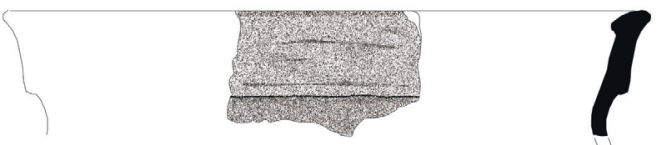

9

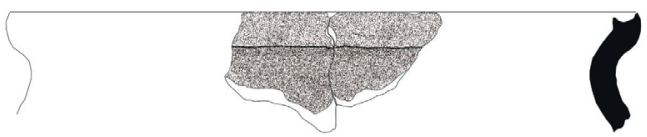

11

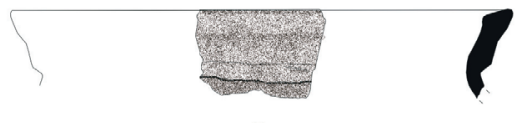

2

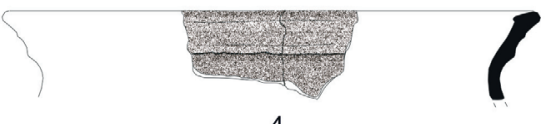

4

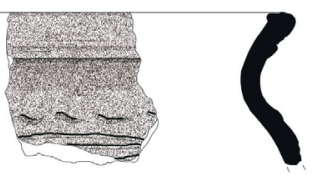

6

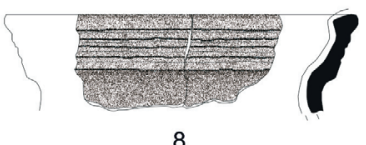

10

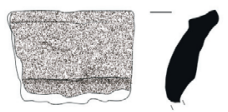

0
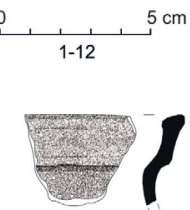

12

Ryc. 6. Grodzisko koło Skały. Wybór fragmentów naczyń ceramicznych z warstwy 7 (rys. M. Wojenka)

Fig. 6. Grodzisko koło Skały. Selection of fragments of pottery vessels from layer 7 (drawing by M. Wojenka)

gwiaździstym, reprezentującą najpewniej odmianę wczesną ${ }^{10}$, mieszczącą się wśród typów A-C (względnie A-D) w ujęciu Stanisława Kołodziejskiego (1985). Egzemplarze te były używane w okresie od połowy XIII do początku lub połowy XIV stulecia. W zbliżonych ramach czasowych, tj. od połowy XIII do początku

${ }^{10}$ Stopień korozji ostrogi uniemożliwił określenie jej cech metrycznych (wszystkie wymienione tu przedmioty metalowe znajdują się obecnie w konserwacji). 
XIV wieku należy też umieścić zbiór naczyń ceramicznych, reprezentowany głównie przez fragmenty garnków wykonanych z glin żelazistych, schudzonych dobrze wyselekcjonowanym drobnym piaskiem i wypalonych przede wszystkim $\mathrm{w}$ atmosferze utleniającej. Ich silnie profilowane brzegi znajdują analogie wśród znalezisk małopolskich datowanych na początek późnego średniowiecza, między innymi z Krakowa - typ 55 według Kazimierza Radwańskiego (1975, s. 356-357, ryc. 128), typy 1-2 według Aliny Wałowy (1979, s. 121) i z Piekar (Leńczyk 1938, tabl. XVI), jak i nieco późniejszych, na przykład z zamku w Białym Kościele (Tutak 2001), który prawdopodobnie funkcjonował jedynie w 1. połowie XIV stulecia (Kołodziejski 1995). Warto również nadmienić, że warstwa 7 zawierała też dużo szczątków zwierzęcych, w tym rybich ${ }^{11}$.

Poniżej warstwy 7 zalegał gruby pokład redeponowanego lessu o zmiennej zawartości gruzu wapiennego (warstwa 10a, c-i; ryc. 5) oraz zgliniony osad o ciemnoszarej barwie (warstwa $10 \mathrm{~b}$ ). $\mathrm{Z}$ warstw tych pochodzi zaledwie kilka ułamków średniowiecznych naczyń ceramicznych, które stwierdzono między innymi w głębiej zalegających warstwach 10c i 10e, czyli w lessie z rumoszem wapiennym (ryc. 5). Nie różnią się one od opisanych wyżej naczyń z warstwy 7. Należy też odnotować, że ciemnoszara warstwa 10b zawierała drobiny węgla drzewnego, lecz nie było w niej innych materiałów źródłowych.

Z uwagi na trudności techniczne nie udało się dotrzeć do spągu warstw redeponowanych, które można określić jako średniowieczne nasypy. Czym podyktowana była konieczność nawiezienia tak ogromnej masy ziemi w rejon centralnej partii zespołu? Jedynym wytłumaczeniem może być zastany przez jego średniowiecznych fundatorów niedostatek miejsca, uniemożliwiający podjęcie planowanej inwestycji budowlanej.

Dokumentacja rzutów poziomych lessu pozwoliła na wyodrębnienie w nim dwóch struktur, których interpretacja nastręcza trudności. Pierwszą był wkop (warstwa 8) o szerokości 120-130 cm, biegnący po przekątnej wykopu (od narożnika południowo-zachodniego do północno-wschodniego), który przecinając less niknął w profilu ściany północnej (ryc. 5). Zwężał się „schodkowato” ku dołowi. Wypełniony był niemal identycznym w składzie i barwie lessem, jaki zalegał w jego otoczeniu. Druga struktura (warstwa $11^{12}$ ) stwierdzona w zachodniej partii wykopu, mniej więcej na poziomie stopy fundamentowej świątyni, miała postać regularnych zaciemnień o układzie poziomym (negatywów konstrukcji drewnianych?), w których sąsiedztwie zarejestrowano koncentrację kamieni wapiennych. Niestety, kontekst stratygraficzny nie dostarczył żadnych znalezisk ruchomych. Być może zaciemnienia te stanowią resztki drewnianego szkieletu konstrukcyjnego, którego zadaniem było stabilizowanie nawiezionych mas ziemi.

\footnotetext{
${ }^{11}$ Skład gatunkowy szczątków zwierzęcych nie został jeszcze określony.

12 Warstwa ta nie jest widoczna na przekrojach poprzecznych (ryc. 5).
} 
W nasypowych warstwach lessowych posadowiono zarówno fundament świątyni, jak i kamienny mur piwnic pod budynkiem domu kapelana (ryc. 4: D). Niestety, nie jest możliwe ustalenie ich chronologii względnej na podstawie analizy układu stratygraficznego w badanej części stanowiska (ryc. 5). Należy jednak odnotować, że warstwa 8, czyli zasypisko wkopu w nasypy średniowieczne, jest stratygraficznie starsze od fundamentu kościoła, posadowionego najpewniej w wykopie wąskoprzestrzennym. Jego zewnętrzną partię tworzą niewielkie kamienie wapienne obficie przelane wapienną zaprawą ${ }^{13}$. O datowaniu fundamentu świątyni trudno się wypowiadać, nie można jednak wykluczyć, że odpowiada on średniowiecznej fazie użytkowania obiektu. Jak wskazują relacje stratygraficzne, niewątpliwie średniowieczną metrykę ma mur piwnic, wzniesiony w wąskim wkopie fundamentowym (warstwa 9); wypełniają go większe kamienie wapienne, tworzące starannie opracowane lico (ryc. 4: D).

$\mathrm{Z}$ zaprezentowanych powyżej danych wynika, że najważniejszym punktem odniesienia dla datowania średniowiecznej aktywności człowieka na terenie późniejszej tzw. Pustelni błogosławionej Salomei są znaleziska z warstwy 7, które zamknąć należy w ramach czasowych od 2. połowy XIII do początku XIV stulecia. Znajdujące się w niej ułamki naczyń ceramicznych najpewniej stanowią pozostałość po użytkownikach obiektu. Czy odpowiadają jej chronologicznie militaria i części oporządzenia jeździeckiego, jest rzeczą otwartą, choć uważam za bardziej prawdopodobne, że są one śladem najazdu, który zamknął średniowieczną historię tego miejsca.

Pierwotne przeznaczenie Grodziska od lat stanowi przedmiot dyskusji, którą w zależności od interpretacji dostępnych przekazów źródłowych da się sprowadzić do dwóch podstawowych hipotez. Według części badaczy (np. Rokosz 1995) obiekt ten utożsamiać należy z wybudowanym przez śląskiego księcia Henryka Brodatego zamkiem Scala, który w źródłach pisanych notowany jest od 1228 roku do przełomu XIII i XIV stulecia. W świetle innej hipotezy Grodzisko jest miejscem warownego klasztoru klarysek księżnej Salomei, który wystawiono na mocy wydanego w 1257 roku przywileju Bolesława Wstydliwego. Książę zezwolił wówczas na przeniesienie konwentu z Zawichostu „w miejsce bezpieczne zwane Skałą" i na wybudowanie tam silnego zamku (KDM, 1, nr 57-58 $\left.{ }^{14}\right)$. Klaryski miały przebywać tam od 1257 lub 1259/1260 do około 1306 roku, zaś kres funkcjonowania klasztoru przyniósł najazd łotrzyków, zapewne rekrutujących się z czynnych lub byłych najemników Jana Muskaty, gorliwego stronnika władzy Przemyślidów ${ }^{15}$. Hipoteza o istnieniu w Grodzisku klasztoru klarysek

${ }^{13} \mathrm{~W}$ licu fundamentu, na głębokości około $60 \mathrm{~cm}$, natrafiono również na mały ułamek cegły.

14 W wieku XIV data roczna emisji tego dokumentu - 1257 (MCCLVII) podmieniona została spóźnioną datą 1262 (MCCLXII) (Rokosz 1995, s. 29).

15 Najazd ten Patrycja Gąsiorowska skłonna jest datować na rok 1298 (Gąsiorowska 2015, s. 79-80). Nieco innego zdania jest Jacek Laberschek, który wiąże zniszczenie konwentu z byłymi już najemnikami Jana Muskaty, około roku 1306 lub nieco później (Laberschek 2016, s. 82). 
ugruntowana została w literaturze przez S. Kołodziejskiego, który zdecydowanie odrzucił możliwość funkcjonowania w tym miejscu grodu Henryka Brodatego ${ }^{16}$. Badacz ten wskazał na zupełnie inną jego lokalizację, w oddalonej o blisko $4 \mathrm{~km}$ na północny zachód wsi Sułoszowej (Kołodziejski 1996; 1997, s. 73-75; 2016, s. 163-165). Koncepcja ta na ogół przyjęła się w literaturze (Laberschek 2000; 2016; Kajzer 2013, s. 118), choć trzeba odnotować i głosy krytyczne, w których zwrócono uwagę przede wszystkim na niewielką powierzchnię zespołu w Grodzisku w stosunku do zakładanych potrzeb przestrzennych klasztoru klarysek (Holcer 2001, s. 354-355 ${ }^{17}$; Pajor 2017).

Choć obserwacje stratygraficzne oraz pozyskany w latach 2016-2017 materiał źródłowy przemawiają na korzyść drugiej ze wspomnianych hipotez, formułowanie ostatecznych wniosków na temat funkcji Grodziska w średniowieczu - zważywszy na długą listę pytań, które wciąż pozostają bez odpowiedzi - uważam za przedwczesne.

\section{Jerzmanowice-Stara Wieś}

$\mathrm{Na}$ mapie średniowiecznego budownictwa obronnego dawnej ziemi krakowskiej niewielka warownia w Jerzmanowicach pojawiła się niedawno ${ }^{18}$. Jej pozostałości położone są w odległości około $20 \mathrm{~km}$ na północny zachód od Krakowa, w obrębie tej części Jerzmanowic, która na mapach katastralnych oznaczana jest jako Stara Wieś (ryc. 1). Znajdują się one na skraju wierzchowiny, tuż przy krawędzi lewego brzegu doliny Szklarki, która przepływa około 70-80 m poniżej ${ }^{19}$. Obiekt obronny założony został w obrębie ostańca wapiennego, którego przybliżone wymiary wynoszą u podstawy około 30×12-20 m, zaś wysokość, mierzona od współczesnego poziomu gruntu, waha się od 10 do 15 m (ryc. 7: A). Po stronie zewnętrznej (północno-zachodniej) ostaniec kończy się potężną ścianą skalną o pionowym przebiegu. Od wewnątrz (od środka warowni) skałka ta jest rozczłonkowana, tworząc swego rodzaju niewielkie (około 3-4×6 m) wypłaszczenie, z jednej strony ograniczone wysoką skałą, $\mathrm{z}$ drugiej stromym stokiem (ryc. 7: B). Na zewnątrz skałki, po jej stronie wschodniej, północno-wschodniej

\footnotetext{
${ }^{16}$ W Grodzisku koło Skały lokalizował wcześniej klaryski J. Laberschek (1989, s. 72).

${ }_{17}$ Według odosobnionej koncepcji Z. Holcera w Grodzisku koło Skały znajdują się pozostałości zamku Leszka Czarnego lub nawet Henryka IV Probusa, dla którego miał on stanowić oparcie w stoczonej w latach 1288-1289 lub w 1290 roku bitwie przeciwko połączonym siłom Władysława Łokietka i Bolesława płockiego (Holcer 2001, s. 365-366).

${ }^{18} \mathrm{Na}$ jej pozostałości autor natrafił na przełomie 2013 i 2014 roku podczas przeglądania numerycznych modeli terenu wykonanych w ramach projektu ISOK, dostępnych w otwartym serwisie www.geoportal.gov.pl. Wcześniej nie była ona znana służbom konserwatorskim, nie wzmiankują jej też żadne znane autorowi opracowania.

19 Bardziej szczegółowy opis tego założenia obronnego oraz rezultatów przeprowadzonych tam prac archeologicznych znajduje się w osobnej publikacji (Wojenka 2016a).
} 

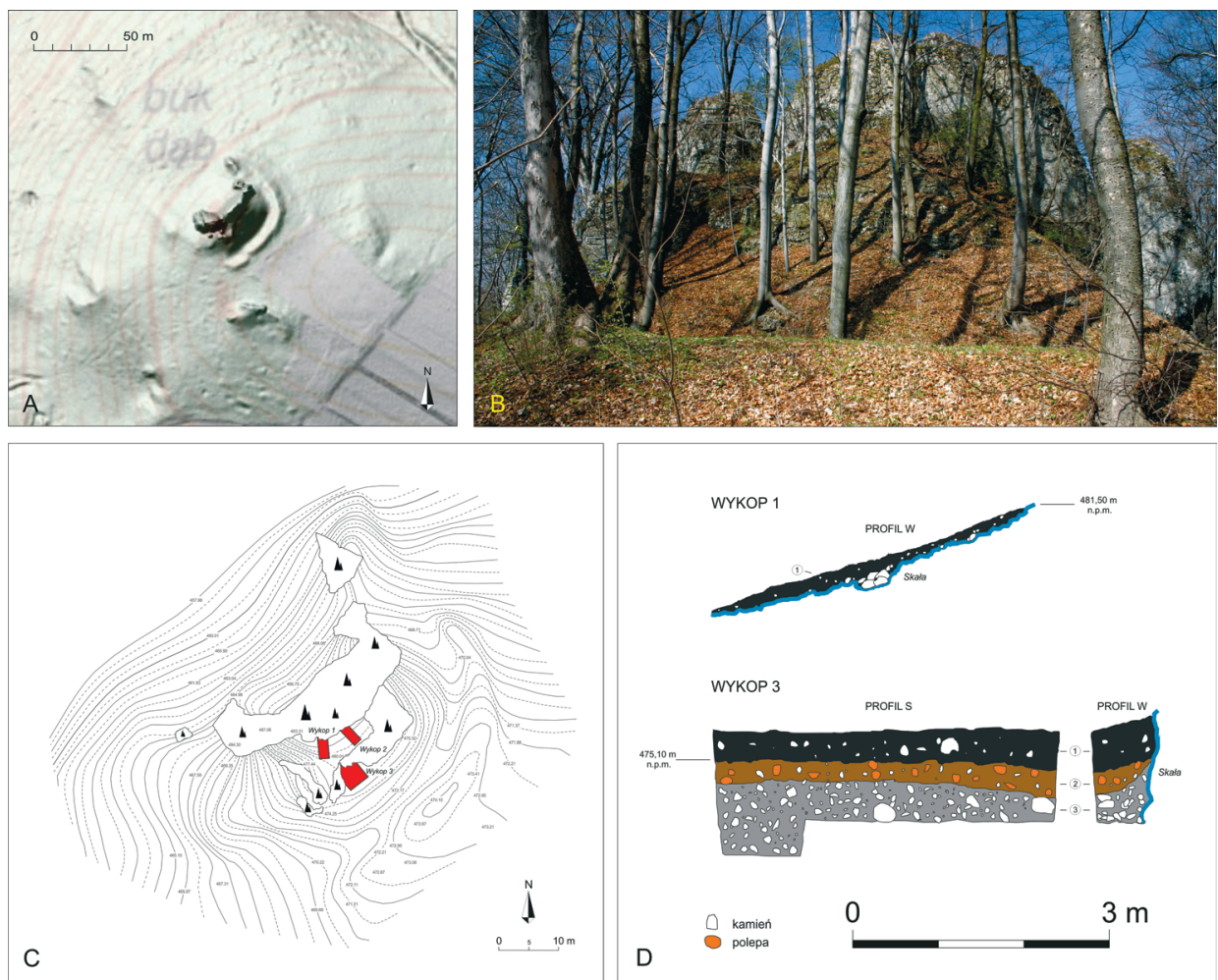

Ryc. 7. Jerzmanowice-Stara Wieś. A - założenie obronne w obrazie lotniczego skaningu laserowego (LiDAR); B - wał obronny i ostaniec - widok od południowego wschodu; C - plan warowni z rozmieszczeniem wykopów eksplorowanych w 2015 roku; D - przekroje wykopów 1 i 2: warstwa 1 -próchnica, warstwa 2 - poziom destrukcji budynku mieszkalnego, warstwa 3 - rumosz wapienny z domieszką próchnicy (A - www.geoportal.gov.pl; B-D - rys. i fot. M. Wojenka)

Fig. 7. Jerzmanowice-Stara Wieś. A - defensive structure in the image of aerial laser scanning (LiDAR); B - rampart and outcrop - view from the south-east; C - plan of the fortress with the location of trenches explored in 2015; D - sections of trenches 1 and 2: layer 1 -humus, layer 2 - level of destruction of dwelling building, layer 3 - limestone rubble with admixture of humus (A - www.geoportal. gov.pl; B-D - drawing and photo by $\mathrm{M}$. Wojenka)

i południowo-wschodniej znajdują się pozostałości wału obronnego, który najczytelniejszy jest w środkowej części obecnego przebiegu (ryc. 7: A-C). Jego szerokość u podstawy nie jest jednolita (w najszerszym miejscu wynosi 6-7 m), uśredniona wysokość waha się od 1,5-2 m od strony wewnętrznej do około $1 \mathrm{~m}$ po stronie zewnętrznej. Wraz z umocnieniami całe założenie zajmowało powierzchnię około 15 arów, mając jednak na uwadze kształt ostańca oraz stromiznę jego stoków wewnętrznych należy przyjąć, że jego przestrzeń użytkowa była raczej niewielka. 
W roku 2015 na terenie warowni przeprowadzono sondażowe badania wykopaliskowe. Założono trzy wykopy - dwa na wypłaszczeniu wewnętrznej partii ostańca (wykopy 1 i 2), trzeci w połowie wysokości jego stoku wewnętrznego, między dwiema mniejszymi skałkami (wykop 3) (ryc. 7: C). Dwa pierwsze nie dostarczyły istotnych obserwacji stratygraficznych (ryc. 7: D). Zalegała tu wyłącznie próchnica $\mathrm{z}$ drobnym gruzem wapiennym, odkładająca się bezpośrednio na podłożu skalnym. Wydobyto z niej około 60 ułamków średniowiecznych naczyń ceramicznych oraz kilka mało charakterystycznych przedmiotów żelaznych ${ }^{20}$. Więcej danych oraz bardziej interesujących znalezisk pochodzi z wykopu 3. Wierzchnią partię jego osadów stanowiła próchnica $\mathrm{z}$ drobnym gruzem wapiennym (w. 1), odkładająca się na kolejnym utworze próchniczym (w. 2), przesyconym bardzo wyraźnymi śladami spalenizny oraz zawierającym liczne (około $130 \mathrm{~kg}$ ) kęsy polepy, w tym również z odciskami konstrukcji (ryc. 8: 19-22), a także ułamki naczyń ceramicznych oraz wyroby metalowe. Poniżej tego nawarstwienia zalegał rumosz wapienny z domieszką próchnicy (w. 3). Nie licząc partii stropowej, w której znaleziono kilka ułamków naczyń, utwór ten był jałowy pod względem archeologicznym. $Z$ powyższych danych wynika, że to w warstwie 2 zachował się najczytelniejszy ślad średniowiecznych dziejów ufortyfikowanego ostańca w Jerzmanowicach. Nagromadzenie polepy z odciskami konstrukcji wskazuje, że mieścił on bliżej nieokreśloną, zapewne drewnianą budowlę, której ściany wypełniała plecionka oblepiona gliną. Wyraźne ślady spalenizny sugerują, że kres funkcjonowania obiektu spowodowany został pożarem. Budynek ten najprawdopodobniej wzniesiono na szczytowym wypłaszczeniu ostańca, zaś o niewielkich rozmiarach jego podstawy wydaje się przekonywać powierzchnia plateau skałki, obecnie ograniczona wymiarami 3-4 ×6 m. Niestety, brak śladów budynku in situ nie pozwala ani na określenie wymiarów, ani na rekonstrukcję jego formy.

Wśród średniowiecznych materiałów ruchomych z wykopu 3 znalazło się blisko 270 fragmentów naczyń ceramicznych oraz 12 przedmiotów żelaznych. Odkryto je głównie w warstwie 2, w związku z tym należy przypisać im rangę datowników poziomu destrukcyjnego domniemanej budowli drewnianej. Fragmenty naczyń ceramicznych $\mathrm{w}$ większości pochodzą z garnków, pojedyncze ułamki to przykrawędne części pokrywek. Wykonano je z glin żelazistych schudzonych domieszką drobnego piasku i wypalono zarówno metodą utleniającą, jak i redukcyjną. Na niektórych okazach wyraźnie widoczne są ślady wtórnego przepalenia (np. ryc. 8: 1). Brzegi garnków są silnie profilowane i w większości analogiczne do egzemplarzy pozyskiwanych na małopolskich stanowiskach archeologicznych z końca wczesnego i z początku późnego średniowiecza (ryc. 8: 1, 2; Radwański 1975, s. 357, ryc. 128, typy 57 i 43; por. też Leńczyk 1938, tabl. XVI, typ 14). Zbiór naczyń ceramicznych z Jerzmanowic należy zatem datować od 2. połowy XIII do początku lub połowy wieku XIV.

${ }^{20}$ Oprócz przedmiotów z okresu średniowiecza w wykopach 1-3 natrafiono na ułamki naczyń ceramicznych i przedmioty metalowe kultury łużyckiej z wczesnej epoki żelaza (Wojenka 2016a, s. 665). 

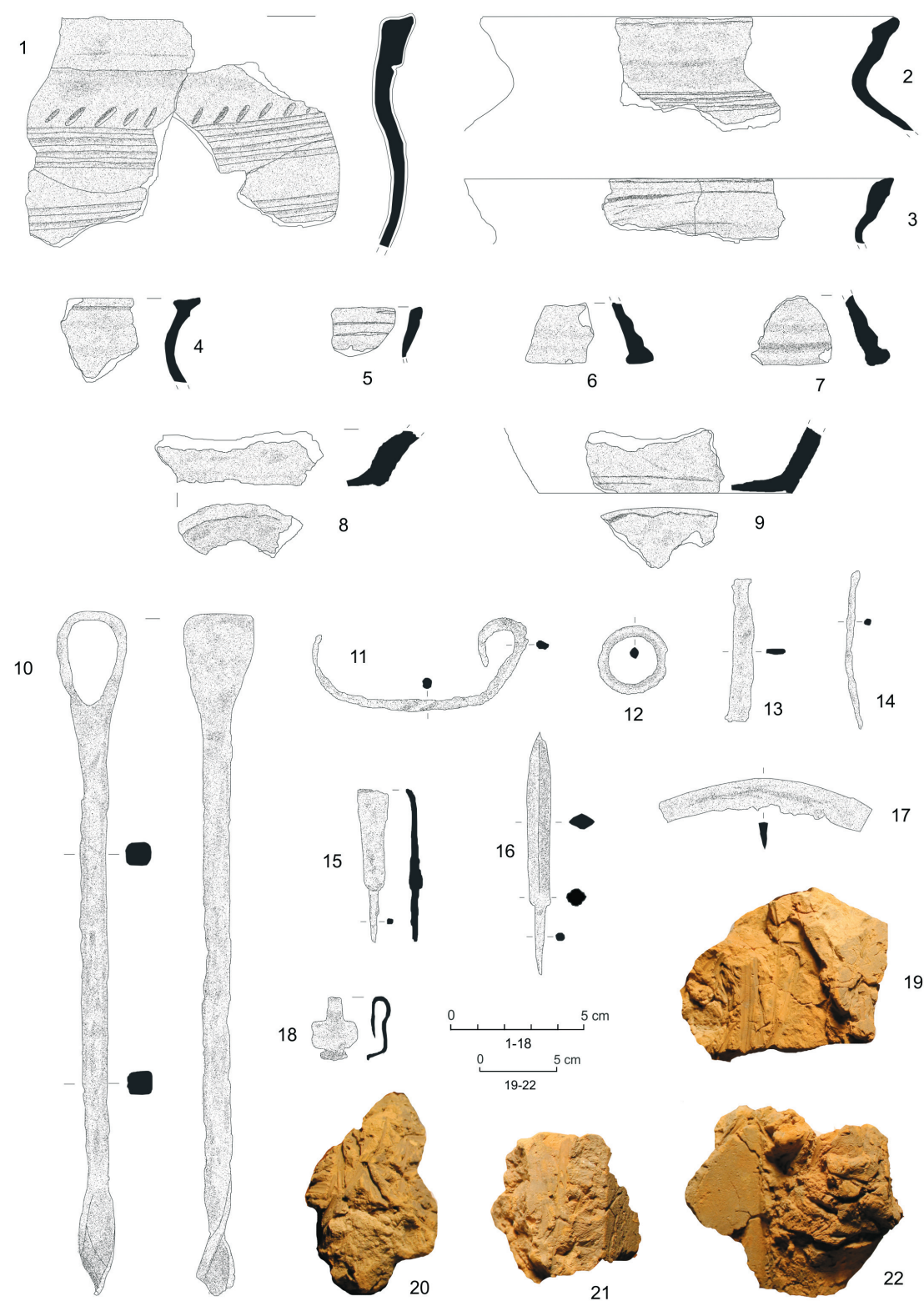

Ryc. 8. Jerzmanowice-Stara Wieś. Wybór materiałów źródłowych: 1-9-fragmenty naczyń ceramicznych; 10-18 - przedmioty z żelaza; 19-22 - polepa (rys. i fot. M. Wojenka)

Fig. 8. Jerzmanowice-Stara Wieś. Selection of source materials: 1-9-fragments of pottery vessels; 10-18 - iron artefacts; 19-22 - scorched clay (drawing and photo by M. Wojenka) 
Wyroby żelazne reprezentowane są przez świder o długości 26,5 cm (ryc. 8: 10), klucz hakowaty (ryc. 8: 11), trudne do dokładniejszego określenia kółko o średnicy 2,8 cm (ryc. 8: 12), ostrze silnie wygiętego noża(?) (ryc. 8: 17), dwa przedmioty nieokreślone (ryc. 8: 13-14) oraz trzy, które zaliczyć można do kategorii oporządzenia jeździeckiego i militariów: element garnituru do przypinania ostrogi (ryc. 8: 18) i dwa groty strzał do łuku, oba odkryte w warstwie 2. Pierwszy z nich charakteryzuje się łukowatym lub deltoidalnym ostrzem liścia (ryc. 8: 15), drugi reprezentuje tzw. typ igłowaty, o silnie wydłużonym, wąskim liściu i graniastym przekroju (ryc. 8: 16). Przedmioty te określić należy jako pozalokalne; podobne wyroby są typowe dla szeroko rozumianego środowiska stepowego, zaś ich pojawienie się w środkowej i wschodniej Europie na ogół wiąże się z ekspansją Mongołów w XIII wieku' ${ }^{21}$.

W świetle powyższych danych z dużym prawdopodobieństwem można przyjąć, że do upadku warowni w Jerzmanowicach przyczynili się ludzie posługujący się łukiem o wschodniej proweniencji. Rozważając okoliczności katastrofy gródka i mając na uwadze datowanie pozyskanego zbioru naczyń, należy wziąć pod uwagę przede wszystkim dwie alternatywne wersje wydarzeń. W pierwszej, którą uważam za najbardziej prawdopodobną, zniszczenie warowni nastąpiło podczas najazdu mongolskiego, zapewne trzeciego (1287/1288 roku), który mógł spustoszyć również Wyżynę Krakowsko-Częstochowską (Krakowski 1956, mapa na wklejce po s. 208, 211, 217; Świętosławski 1997, mapa po s. 114). W drugiej wersji wydarzeń znaleziska militarne z Jerzmanowic mogłyby odzwierciedlać rodzaj wyposażenia wojsk przysłanych na pomoc Władysławowi Łokietkowi przez księcia ruskiego Lwa, syna Daniela Halickiego w 1289 roku, w celu zdobycia przez niego Krakowa (Kronika 2017, s. 262-263; por. też Długopolski 2009, s. 15-16) ${ }^{22}$.

Niestety, wobec braku źródeł pisanych, wskazanie fundatora interesującego nas założenia obronnego nie jest obecnie możliwe. Miejscowość Jerzmanowice w źródłach pisanych po raz pierwszy odnotowano dopiero w 1335 roku (Hermani Villa; Laberschek 1995, s. 168).

\section{Dubie}

W południowo-zachodniej części Jury Ojcowskiej, na lewym brzegu Racławki w miejscowości Dubie, położone jest porośnięte lasem bukowym, wyniosłe wzgórze (452 m n.p.m.) o bardzo stromych stokach, które na mapach katastralnych oznaczono znamienną nazwą Zamczysko (ryc. 1). W jego południowej, cyplowato

\footnotetext{
${ }^{21}$ Uwaga ta w szczególności odnosi się do okazów o liściu łukowatym/deltoidalnym (Medvedev 1966a, s. 75-76; 1966b, s. 55-56; por. również Świętosławski 1997, s. 75-78, 88-89).

${ }^{22}$ Groty z Jerzmanowic nie są jedynymi znaleziskami wiązanymi z najazdem ludzi wywodzących się ze środowiska stepowego na Wyżynie Krakowsko-Częstochowskiej (Wojenka 2016a, s. $670-671-$ tam dalsza literatura).
} 
ukształtowanej partii, która obniżona jest względem wierzchołka o około $80 \mathrm{~m}$, znajdują się nikłe pozostałości dawnego obiektu obronnego, który uważać można za budowlę wieżową. Obiekt ten zachował się jedynie w przyziemiu, które w rzucie poziomym ma kształt zbliżony do kwadratu. Te jego partie, które przetrwały do naszych czasów, wzniesione zostały z miejscowego dolomitu ${ }^{23}$.

Pozostałości wieży znajdują się w północnej części dość nierównego plateau o wymiarach $20-25 \times 10 \mathrm{~m}$, którego krawędzie południowa i wschodnia przechodzą w ostry stok, zachodnia zaś kończy się urwiskiem. Od strony północnej i północno-zachodniej plateau wraz z reliktem budowli odcięte jest od pozostałej części wzgórza głębokim, w większości zapewne sztucznie uformowanym parowem, pełniącym funkcję suchej fosy. Widoczne w jej ścianach i na dnie odkrywki dolomitu sugerują, że podczas przekopywania fosy fundator założenia mógł jednocześnie pozyskiwać surowiec potrzebny do prac budowlanych.

Podobnie jak warownia w Jerzmanowicach, również i wieża w Dubiu stosunkowo późno weszła w obieg naukowy badaczy zajmujących się dziejami średniowiecznej architektury militaris ${ }^{24}$. Jako pierwszy zwrócił na nią uwagę Michał Uruszczak, który jest również autorem wstępnej inwentaryzacji obiektu (Uruszczak 2003). W świetle jego ustaleń relikty budowli wieżowej są zbliżone do czworoboku o wymiarach $4,7 \times 6,4 \mathrm{~m}$, z przyporą od strony wschodniej, zaś na podstawie opublikowanego planu obiektu szerokość jego murów określić należy na około 1 m (Uruszczak 2003, s. 203,208). Chciałbym tu zaznaczyć, że cytowany autor zastrzegał wstępny charakter inwentaryzacji i postulował przeprowadzenie bardziej szczegółowych badań (Uruszczak 2003, s. 203-204).

W 2016 roku przeprowadzono badania weryfikacyjne, polegające na wstępnym odczyszczeniu słabo czytelnych w terenie koron murów budowli i założeniu niewielkiego $(1,5 \times 1,5 \mathrm{~m})$ wykopu sondażowego w północno-wschodnim narożniku jej wewnętrznej partii (wykop 1). Wykonano również plan geodezyjny stanowiska (ryc. 9: A). Wyniki pozwoliły na weryfikację planu obiektu oraz umożliwiły ustalenie grubości jego murów. W ich świetle należy przyjąć, że budowla wieżowa w Dubiu założona została na planie kwadratu(?) o długości boków około 7,5 m, zaś szerokość jej murów w części przyziemnej oscylowała wokół 2-2,15 m (ryc. 9: B). Zrekonstruowane wymiary wnętrza zachowanej partii obiektu wynoszą około 2,8 $\times 2,8 \mathrm{~m}$. Tym samym nie potwierdziły się wcześniejsze przypuszczenia o obecności przypory w jej wschodniej częścici ${ }^{25}$.

${ }^{23}$ W bezpośrednim sąsiedztwie obiektu, u wylotu Wąwozu Zbrza, znajduje się czynny do dzisiaj kamieniołom dolomitów (Gradziński, Gradziński, Michalik 1994, s. 44).

${ }^{24}$ Należy jednak odnotować, że obiekt ten dostrzeżono wcześniej w opracowaniu poświęconym geologii okolic Krakowa (Gradziński 1972, s. 79).

${ }^{25}$ Należy dodać, że na zdjęciu z lotniczego skaningu laserowego (LiDAR) na południowy wschód od plateau, w niższej partii cypla, widoczna jest niewysoka struktura o liniowym przebiegu, sprawiająca wrażenie dodatkowych umocnień (wg www.geoportal.gov.pl; por. też Bereszyński 2006, s. 20). 

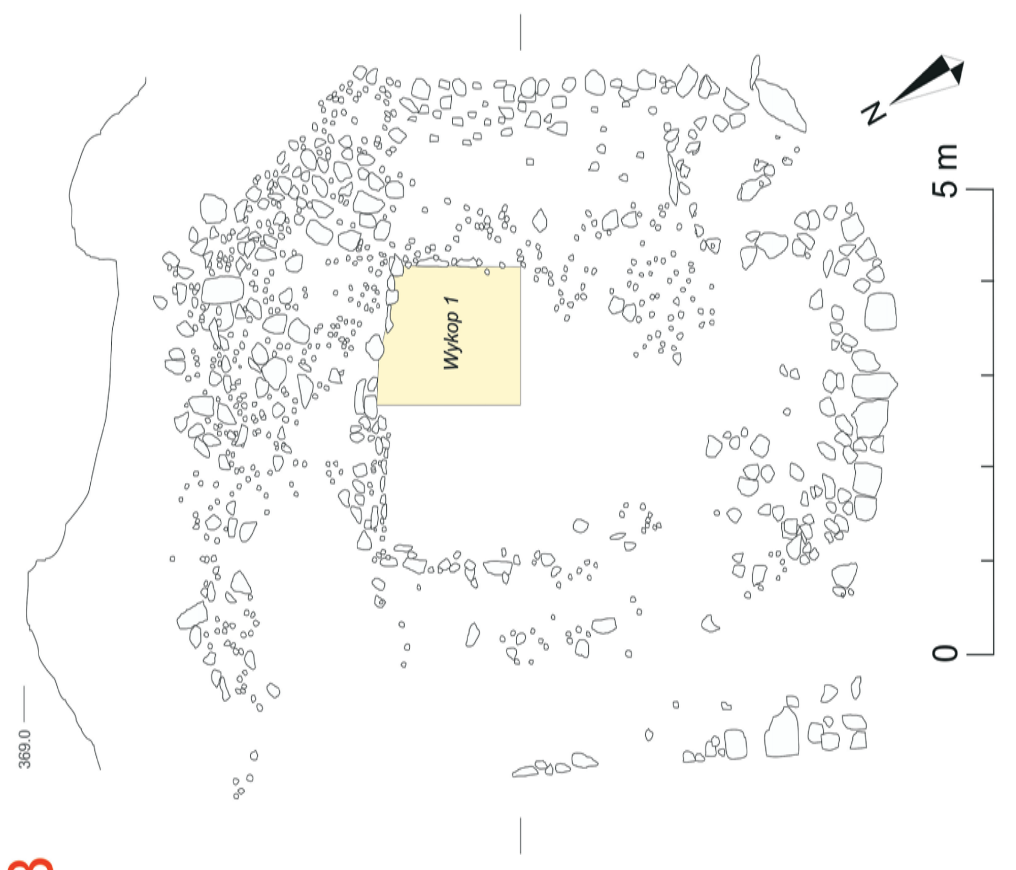

m

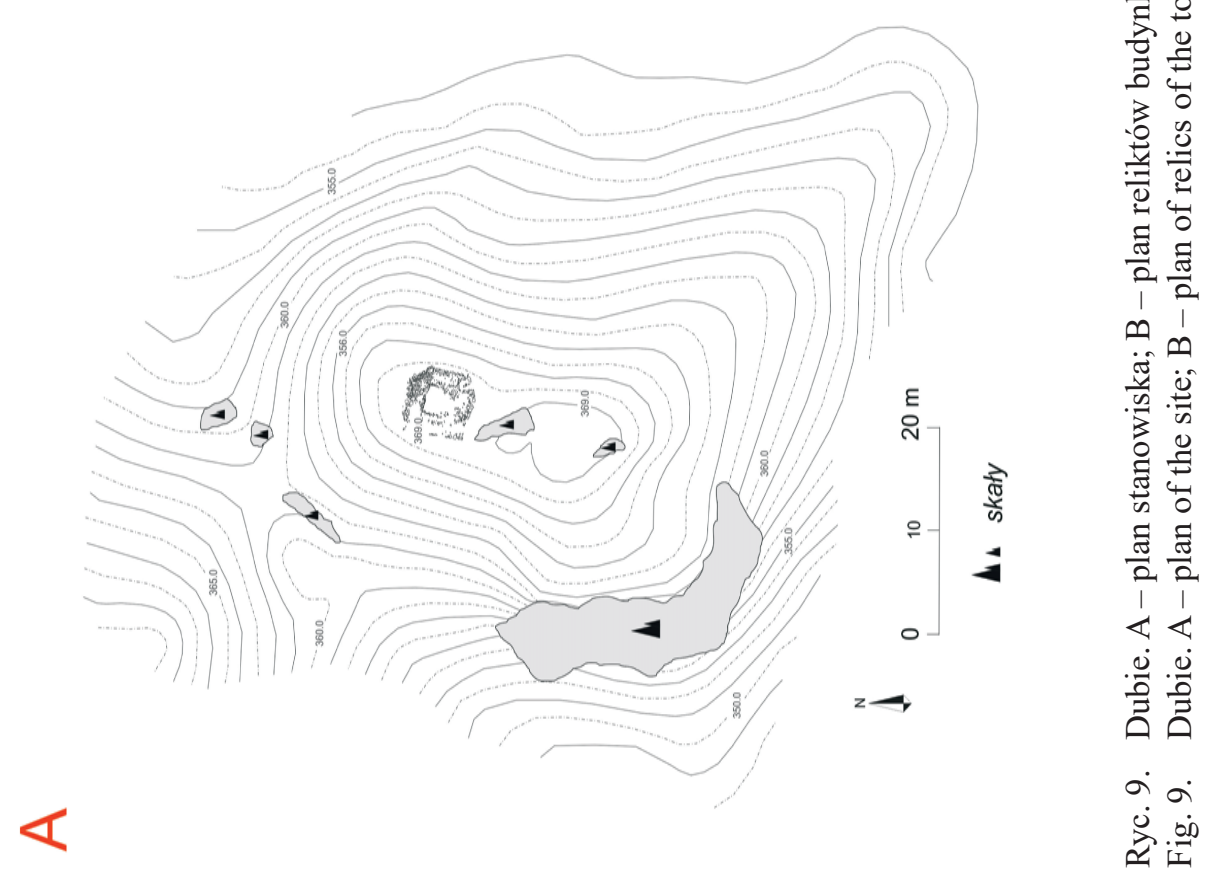


Mimo bardzo złego stanu zachowania można podejrzewać, że mury budowli wzniesiono w technice opus emplectum. Świadczy o tym starannie opracowany budulec $\mathrm{w}$ jej licu zewnętrznym i wewnętrznym, w którym widoczne są między innymi większe (około $30 \times 20-25 \mathrm{~cm}$ ) bloki dolomitu, podczas gdy w grubości muru występują przede wszystkim kamienie mniejszych rozmiarów. Wnętrze muru przelane jest zaprawą wapienną, miejscami zachowaną również w licu wieży.

Założony wewnątrz budowli sondażowy wykop 1 nie dostarczył informacji umożliwiających dokładne datowanie obiektu. Stwierdzono w nim wyłącznie warstwę próchnicy o miąższości $20-25 \mathrm{~cm}$, odkładającą się na naturalnym podłożu skalnym. Natrafiono zaledwie na jeden ułamek naczynia ceramicznego, pochodzący z przydennej partii garnka wykonanego z żelazistej gliny, schudzonej drobnym piaskiem i wypalonego $w$ atmosferze utleniającej. Trzy niecharakterystyczne ułamki naczyń (w tym jeden z plamkami oliwkowego szkliwa) pozyskano w trakcie oczyszczania koron murów. Przyniosło ono ponadto znaleziska kilkunastu mniejszych kęsów polepy, w tym również z odciskami konstrukcji. Konkludując, na podstawie materiału źródłowego funkcjonowanie wieży mieszkalnej w Dubiu można odnieść tylko ogólnie do późnego średniowiecza.

Nieliczne znaleziska nakazują zastanowić się, czy opisywana budowla wieżowa w ogóle doczekała się realizacji. Mimo rozczarowujących rezultatów badań uważam, że na pytanie to należy odpowiedzieć twierdząco. Przemawia za tym obecność polepy z odciskami konstrukcji oraz lokalna nazwa Zamczysko, świadcząca o utrzymującej się wśród miejscowej społeczności pamięci o mieszkalno-obronnych funkcjach tego miejsca.

$\mathrm{Z}$ uwagi na brak źródeł pisanych wskazanie fundatora budowli wieżowej nie jest możliwe. Nazwa miejscowa Dubie pojawiła się w źródłach dopiero w 1381 roku (Sikora 1986, s. 619, 625). Warto jednak zwrócić uwagę na fakt, że przynajmniej od początku wieku XIV najbliższa okolica stanowiła obszar zainteresowań gospodarczych rodu Toporów, których własność między innymi w częściach wsi Dubie i w pobliskich Pisarach poświadczona jest od schyłku XIV stulecia (Kurtyka 1997, s. 67-68). W latach 1397-1409 z Dubia i Pisar pisał się chorąży krakowski Żegota herbu Topór, o którego niebagatelnej karierze najlepiej świadczy fakt, że w roku 1403 miał dom na zamku krakowskim (Sikora 1986, s. 620). Wobec powyższego należy stwierdzić, że z całą pewnością jego finanse pozwalały na wzniesienie budowli wieżowej w rodowym Dubiu. Nie można też wykluczyć, że jej fundatorem był odnotowany w latach 1398-1408 brat Żegoty - Śmił bądź też któryś z przodków obu braci (Sikora 1986, s. 620; Bereszyński 2006, s. 21). 


\section{Ojców}

Położony na wzgórzu wapiennym w centralnej części Ojcowa zamek należy do najcenniejszych pamiątek doby średniowiecza na Wyżynie Krakowsko-Częstochowskiej (ryc. 1). Jak wskazują źródła pisane, jego budowę należy wiązać z osobą Kazimierza III Wielkiego. Po raz pierwszy wymieniony w nich został w 1370 roku, gdy na wystawionym w Krakowie dokumencie króla świadkował Zaclica burgrauio de Oczecz (KDM 3, nr 834). Zamek Oczecz wymieniono również w anonimowym tekście Quomodo regebat regnum et populum, w którym umieszczono go na liście fundacji Kazimierza Wielkiego (Kętrzyński 1897, s. 351; Jan z Czarnkowa 2001, s. 15-19). Dokładnej daty rozpoczęcia jego budowy co prawda nie znamy, jednak przekonujące argumenty Jacka Laberscheka wskazują, że doszło do niej najwcześniej w roku 1354, kiedy to król Kazimierz w drodze zamiany z biskupem krakowskim Bodzantą wszedł w posiadanie znajdującej się nieopodal wsi Smardzowice. Jak wynika z jego ustaleń, zamek ojcowski stanął właśnie na gruntach wspomnianej miejscowości (Laberschek 1996, s. 270), zatem należy przyjąć, że rozpoczęcie prac budowlanych na zamku nastąpiło w okresie między 1354 a 1370 rokiem.

Przed 1385 rokiem warownia ojcowska została zastawiona i od tej pory, aż do ostatniego rozbioru Rzeczpospolitej znajdowała się w rękach prywatnych, choć formalnie wciąż była własnością królewską (Falniowska-Gradowska 1995; 1999). Dzieje zamku jako obronnej rezydencji dopełniły się wraz z początkiem wieku XIX, zaś niedługo później, przynajmniej od 1829 roku, rozpoczęto systematyczną rozbiórkę jego murów. Obecnie czytelne są tylko niektóre elementy dawnego układu przestrzennego (ryc. 10).

Ruiny zamku ojcowskiego od 2006 roku (z przerwami) są przedmiotem archeologicznych badań wykopaliskowych (por. ostatnio Wojenka 2016b). W roku 2016 koncentrowano się w rejonie tzw. wieży ośmiobocznej, położonej w północno-zachodniej części zamku, na wypłaszczeniu wapiennej skałki stanowiącej najwyższy punkt wzgórza (ryc. 10). Dolne partie wieży, wraz z zewnętrzną arkadą bramy i dolną partią jej arkady wewnętrznej należy uznać za najstarsze i najlepiej zachowane elementy pierwotnego zamku gotyckiego (Frazik 1966, s. 32). Wieża zbudowana została na planie oktagonu o szerokości (średnicy) $11,55 \mathrm{~m}$ i długości boków około 4,8 m. Jej wnętrze ma kształt kolisty, o średnicy 6,2 m. Grubość muru wynosi średnio 2,7-2,8 m.

Wieżę zbudowano z regularnych bloków kamiennych o wymiarach: $36-52 \mathrm{~cm}$ wysokości, 60-80 cm długości i 36-52 cm szerokości (Frazik 1966, s. 31). Należy podkreślić, że jedynie dolne partie obiektu stanowią pamiątkę średniowiecznych dziejów zamku. Górna część to efekt prac rekonstrukcyjnych wykonanych 




Ryc. 10. Zamek w Ojcowie. Plan stanowiska z uwzględnieniem obszaru badań przeprowadzonych w 2016 roku: 1 - relikty mostu prowadzącego do przejścia bramnego; 2 - wieża bramna; 3 - relikty domu mieszkalnego; 4 - wieża ośmioboczna; 5 - relikty muru obwodowego; 6 - studnia (rys. M. Wojenka)

Fig. 10. Castle in Ojców. Plan of the site including the research area in 2016: 1 - relics of the bridge leading to the gateway; 2 -gate tower; 3 -relics of dwelling house; 4 - octagonal tower; 5 - relics of the perimeter wall; 6 -well (drawing by M. Wojenka) 
w latach 1912-1914 (Falniowska-Gradowska 1999, s. 81). Za wtórny w stosunku do pierwotnej realizacji wieżowej należy uważać także obecny otwór wejściowy oraz okna zachowane na poziomie pierwszej i drugiej kondygnacji, które wymurowano między innymi z cegieł o wymiarach 5,5-6 × 13 × 26-27 cm. Za późne, bo wzniesione z cegieł o zbliżonych wymiarach, trzeba również uznać zrujnowane elementy wyposażenia wnętrza budowli - zachowany w przyziemiu kominek oraz dwa osklepione zagłębienia, zapewne służące za schowki.

Przeprowadzone w 2016 roku badania wykopaliskowe nie były pierwszymi, które zrealizowano w rejonie ośmiobocznej wieży. Pierwsze obserwacje stratygraficzne dotyczące zaplecza tego obiektu przypadły w udziale Krystynie Kruczek, która w 1991 roku badała rejon obecnego wejścia do obiektu (wykop V/1991; ryc. 10). U jego podnóża natrafiła na ,,mur kamienny wykonany w konstrukcji opus emplectum", posadowiony bezpośrednio na skale; uznała go za rodzaj podpory, zabezpieczającej wieżę przed osuwaniem się (Kruczek 2001, s. 398). W 2016 roku założono trzy wykopy badawcze (ryc. 10), usytuowane na północ od masywu wieży (wykop VII; 3,5 × 6,5 × 3 m), w jej wnętrzu (wykop VIII; 5,1 × $1 \mathrm{~m}$ ) oraz po zachodniej stronie, w obrębie dzisiejszego tarasu widokowego (wykop IX; $10 \times 3-5 \mathrm{~m}$ ). We wszystkich zarejestrowano nieskomplikowaną sytuację stratygraficzną, wszędzie też stosunkowo płytko pojawiło się naturalne podłoże skalne; miąższość osadów w wykopie VII wynosiła maksymalnie $100 \mathrm{~cm}$, w wykopie VIII 10-15 cm, w wykopie IX 60-70 cm (ryc. 11: A-B).

W wykopie VII pod warstwą wierzchniej próchnicy (warstwa 1) odsłonięto fundament silnie zniszczonego muru z kamieni wapiennych, o szerokości 110-120 cm, ciągnącego się od lica wieży w kierunku północnym. Przecinał on przynajmniej jedno nawarstwienie o cechach nasypu, zawierające materiał z końca średniowiecza lub XVI wieku. Redeponowany materiał ze wspomnianej warstwy stwierdzono też w dolnej części wypełniska wkopu fundamentowego pod wspomniany mur (warstwa 2b; ryc. 11: A.2). Datowanie muru odnieść należy do okresu nowożytnego, na co wskazują znaleziska $\mathrm{z}$ wkopu fundamentowego oraz zachowana w wątku kamiennym cegła o wymiarach główki $6 \times 10 \mathrm{~cm}$ (ryc. 11: A.3) ${ }^{26}$. Poniżej zalegała warstwa zaprawy murarskiej (warstwa 6) o miąższości 50-60 cm, zawierająca nieliczne ułamki późnośredniowiecznych naczyń ceramicznych. W przeważającej części wykopu odkładała się ona bezpośrednio na skale wapiennej, wyjąwszy partię środkową, w której zalegała na stropie nieco jaśniejszej warstwy z zaprawą (warstwa 7), pod którą natrafiono na koncentrację polepy z odciskami konstrukcji (warstwa 8; ryc. 11: A.2). Poniżej rejestrowano już wyłącznie skałę macierzystą, nierówną i pełną naturalnych szczelin, które wypełniano kamieniami wapiennymi i przelewano zaprawą murarską. Zabieg ten miał na celu uzyskanie odpowiednio wyrównanego i ustabilizowanego podłoża

\footnotetext{
${ }^{26}$ Mur ten został zaznaczony na planie zamku autorstwa Wilhelma Giersza, sporządzonym w roku 1829 (Wróblewski 1907, s. 130).
} 
A
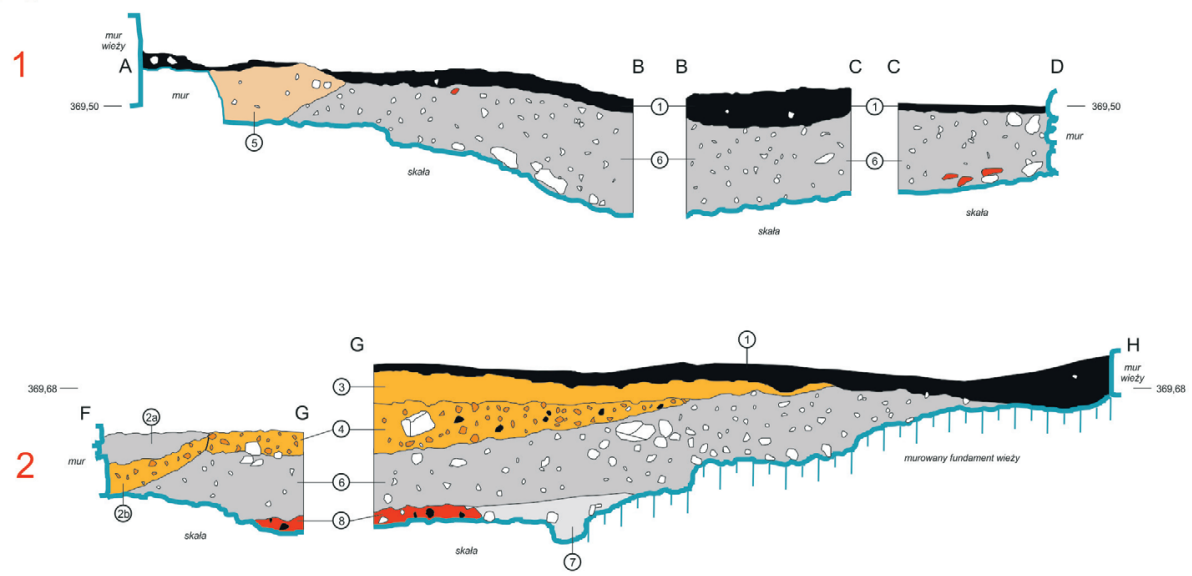

3
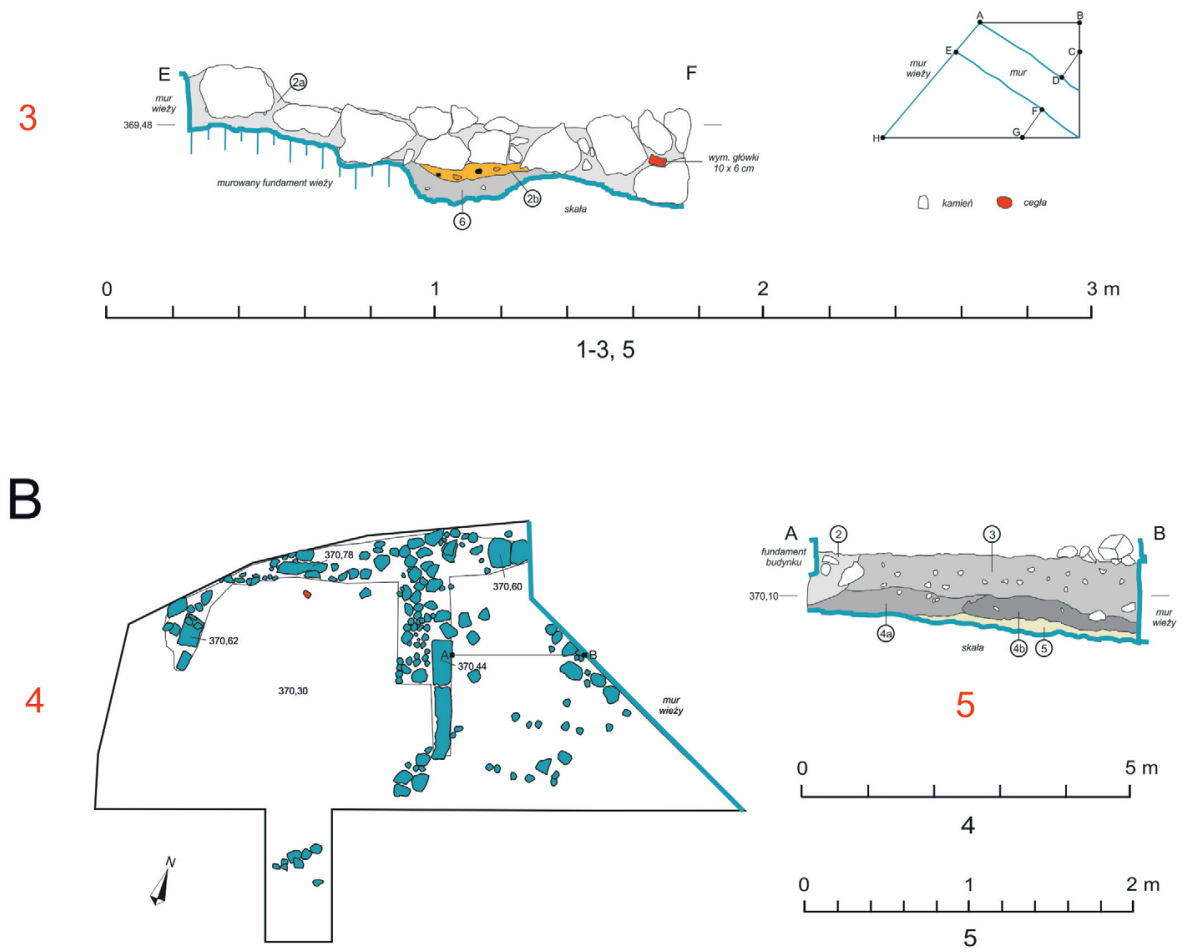

5

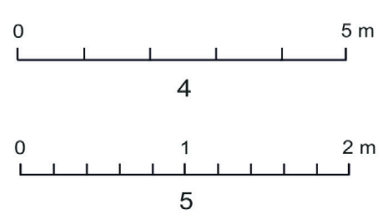


i zapewne poprzedzał budowę wieży. Można przypuszczać, że podobną funkcję stabilizującą pełnił też wspomniany mur wykonany w technice opus emplectum, odsłonięty przez K. Kruczek w wykopie V/1991.

Badania we wnętrzu wieży (wykop VIII) nie dostarczyły istotnych informacji. Na całej eksplorowanej powierzchni zalegał na ogół pylasty osad nasypowy o miąższości zaledwie 10-15 cm, w którym zachowało się kilka ułamków nowożytnych naczyń ceramicznych. Odkładał się on bezpośrednio na celowo wyrównanej skale wapiennej, zaobserwowanej w obrębie całego wykopu, w tym wewnątrz lewego, osklepionego zagłębienia-schowka. Tym samym odrzucić należy pogląd wyrażony w pochodzącym z początku XX wieku przewodniku po Ojcowie, którego autor podaje, jakoby schowek ów miał kryć zawalone kamieniami ,wejście do lochów podziemnych" (Wróblewski 1907, s. 133).

Interesujących odkryć dokonano natomiast w wykopie IX, założonym na tarasie widokowym po zachodniej stronie wieży. Natrafiono w nim na kamienne pozostałości fundamentu budynku o rekonstruowanych wymiarach 4,5-5 × 4,5-5 m i grubości murów około $80 \mathrm{~cm}$. Posadowiono go na sztucznie wyrównanym podłożu skalnym (ryc. 12). Wejście znajdowało się od strony wschodniej, o czym świadczy zachowana belka progowa z wtórnie użytego detalu architektonicznego (ryc. 11: B.4, ryc. 12). W partii północno-wschodniej obiekt połączony był z licem wieży krótkim odcinkiem muru z kamieni wapiennych o nieokreślonej grubości,

Ryc. 11. Zamek w Ojcowie. A - przekroje poprzeczne i podłużne wykopu VII: warstwa 1 - próchnica; warstwy $2 \mathrm{ab}$ - zasypisko wkopu fundamentowego pod mur nowożytny; warstwa 3 -glina; warstwa 4 - glina z polepą i spalenizną; warstwa 5 - zaprawa wapienna zmieszana z próchnicą; warstwy 6, 7 - zaprawa wapienna; warstwa 8 - skupisko polepy. B - plan reliktów budynku z końca XV lub 1. połowy XVI wieku, odsłoniętego w wykopie IX (4) oraz przekrój AB (5) w wykopie IX: warstwa 2 - zasypisko wkopu fundamentowego pod mur budynku; warstwy 3, 4ab - zaprawa wapienna; warstwa 5 - zaprawa wapienna i zwietrzelina skalna (rys. M. Wojenka)

Fig. 11. Castle in Ojców. A - sections of trench VII: layer 1 - humus; layers 2ab - backfill of the foundation trench of the post-medieval wall; layer 3 - clay; layer 4 - clay with daub and scorch; layer 5 - lime mortar mixed with humus; layers 6, 7 - lime mortar; layer 8 - scorched clay concentration. B - plan of relics of the building from the end of the $15^{\text {th }}$ or the first half of the $16^{\text {th }}$ century unearthed in trench IX (4) and section AB (5) in trench IX: layer 2 - backfill of the foundation trench of building wall; layers 3, 4ab - lime mortar; layer 5 - lime mortar and rock debris (drawing by M. Wojenka) 


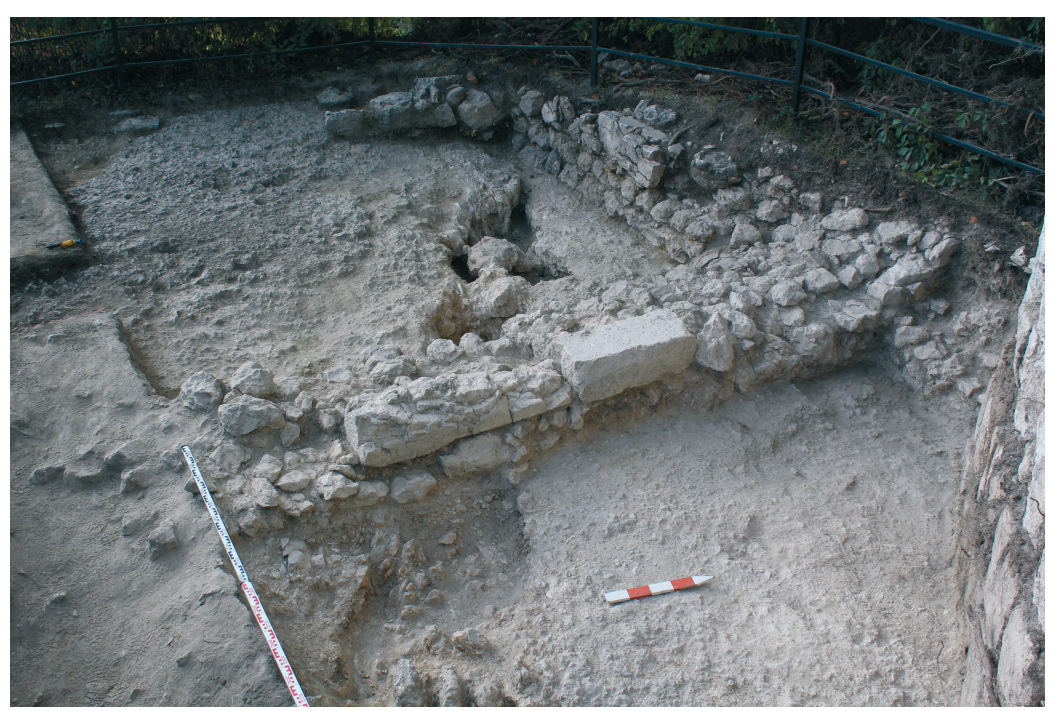

Ryc. 12. Zamek w Ojcowie. Relikty budynku z końca XV lub 1. połowy XVI wieku, odsłonięte w wykopie IX; widok od wschodu (fot. M. Wojenka)

Fig. 12. Castle in Ojców. Relics of the building from the late $15^{\text {th }}$ or first half of the $16^{\text {th }}$ century unearthed in trench IX; view from the east (photo by M. Wojenka)

posadowionego na skale macierzystej ${ }^{27}$. Jak wskazują materiały ceramiczne (m.in. ułamki naczynia z gliny białej, zdobionego ciemnopomarańczową malaturą) z wkopu fundamentowego pod jego podwalinę (warstwa 2; ryc. 11: B.5), budynek postawiono w końcu XV lub, co bardziej prawdopodobne, dopiero w 1. połowie XVI wieku. Wobec braku o nim wzmianek w dostępnych mi źródłach pisanych, nie mogę określić jego funkcji.

Na wschód od wspomnianego budynku zalegały wyłącznie nawarstwienia budowlane z dużym udziałem zaprawy murarskiej (warstwy 3, 4ab, 5; ryc. 11: B.5) oraz gruzowiskiem w stropowej partii, które zawierało okruchy i większe fragmenty detali architektonicznych z wapienia, pochodzących niewątpliwie z gotyckiej fazy zamku, w tym elementy kamieniarki okiennej(?) o profilu ,jednogruszkowym" przechodzącym we wklęski (ryc. 13: 1-2) oraz obramienia okna lub portalu, zachowanego w postaci ćwierćwałka obustronnie ujętego w płytkie wcięcia, z których jedno przechodzi w łagodną, obszerną wklęskę (ryc. 13: 3). Z najwyższym stopniem prawdopodobieństwa należy przyjąć, że wzmiankowany detal pierwotnie znajdował się w wieży i decydował o jej wysmakowanym, bardzo reprezentacyjnym wystroju. Kamieniarkę tę należy wiązać z wczesnymi fazami rozwoju zamku, nie wykluczając, że odpowiada ona jeszcze realizacji kazimierzowskiej. Pierwotnie zdobiła ona zapewne kondygnację reprezentacyjną

${ }^{27}$ Wymiarów muru nie udało mi się określić $\mathrm{z}$ uwagi na urwisko znajdujące się po jego zewnętrznej stronie, uniemożliwiające bezpieczną eksplorację. 

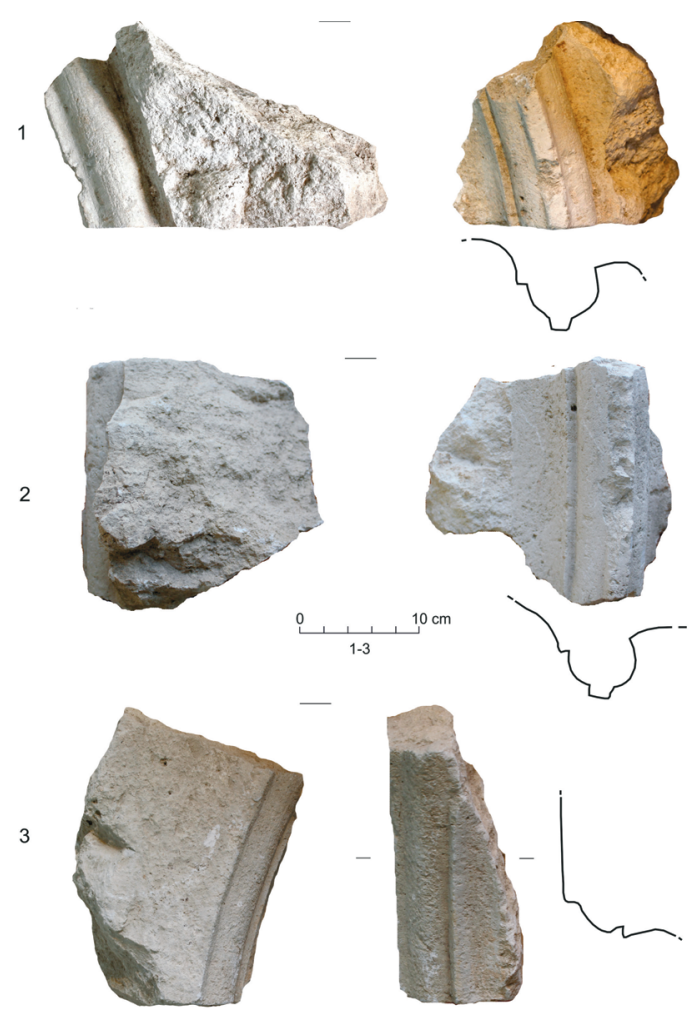

Ryc. 13. Zamek w Ojcowie. Gotyckie detale architektoniczne (rys. i fot. M. Wojenka) Fig. 13. Castle in Ojców. Gothic architectural details (drawing and photo by M. Wojenka)

lub mieszkalną, choć nie można wykluczyć, że stanowiła o wystroju kaplicy, dowodnie poświadczonej wzmianką o kapelanie zamkowym o imieniu Jan w 1397 roku (Laberschek 1993, s. 18). Opisany detal uzupełnia skromne, bo liczące dotąd tylko cztery okazy „lapidarium gotyckie” z zamku ojcowskiego ${ }^{28}$, za to jako całość świadczące o doskonałości warsztatowej, która w skali królewskich rezydencji małopolskich znajduje odpowiedniki właściwie tylko na Wawelu (Stępień 2000/2001; Ratajczak 2014) oraz w pałacu na zamku w Szydłowie, datowanym od końca XIV do 3. dekady XV wieku (Frazik 1966, s. 32; Olszacki 2011, s. 265; 2017, s. 978-979).

W świetle dokonanych odkryć należy zatem przyjąć, że ośmioboczna wieża zamku w Ojcowie pierwotnie pełniła funkcję rezydencjonalną. Nie licząc

${ }_{28}$ Dwa detale wmurowano wtórnie w nowożytny mur obwodowy (Frazik 1966, s. 32, ryc. 5, fot. 6, s. 33, fot. 7), trzeci, stanowiący fragment obramienia prostokątnego okna o węgarze profilowanym wałkiem z noskiem (,gruszką”), użyto jako wtórnik w murach XVIII-wiecznej kaplicy (Niewalda, Rojkowska 2001, s. 434, ryc. 10). O czwartym okazie, pozyskanym w rejonie muru tzw. domu wschodniego, informuje K. Kruczek (2001, s. 398). 
zaprezentowanego wyżej detalu architektonicznego, za jej mieszkalnym charakterem do pewnego stopnia przemawiają też odkryte w 2016 roku fragmenty późnośredniowiecznych importowanych naczyń kamionkowych oraz ułamek kafla płytowego z motywem drzew (palm?), pokrytego zielono-oliwkowym szkliwem, który pośrednio wskazuje na ogrzewanie któregoś ze znajdujących się w wieży pomieszczeń piecem kaflowym ${ }^{29}$. Obie wspomniane kategorie źródeł skłonny jestem datować ogólnie na wiek XV.

Na zakończenie chciałbym odnieść się do kwestii datowania warstw budowlanych w wykopach VII i IX. Większość z nich - o ile nie wszystkie - wbrew pozorom wcale nie pochodzi z czasów budowy wieży, lecz poświadcza jej XV-wieczną przebudowę lub nadbudowę. Przemawiają za tym trzy monety z czasów jagiellońskich, pozyskane z warstwy $3 \mathrm{w}$ wykopie IX: wycięty z półgrosza denar Władysława Jagiełły oraz dwa denary Kazimierza Jagiellończyka, datujące wspomnianą warstwę najwcześniej na lata 1455-147930. Trudno stwierdzić, czy w tym samym czasie odłożyły się wokół wieży również pozostałe nawarstwienia z zaprawą murarską, trzeba jednak zauważyć, że na ich stropie nie zdecydowano się na ułożenie bruku kamiennego ${ }^{31}$, co kontrastuje $\mathrm{z}$ rezydencjonalną funkcją budowli. Zatem prawdopodobnie w czasie akumulacji warstw z zaprawą wieża nie służyła już za mieszkanie.

Poszukując przyczyn nagromadzenia się warstw budowlanych wokół wieży chciałbym zwrócić uwagę na najstarsze przedstawienie zamku ojcowskiego - akwarelę Zygmunta Vogla z 1787 roku. Na dwóch najwyżej położonych kondygnacjach wieży widnieje znaczne zagęszczenie otworów okiennych, które jak się wydaje, są nieco mniejsze niż oba okna położone na piętrach niższych (ryc. 14). Jeśli najwyżej położona partia przedstawionych okien nie stanowi śladu po zamurowanym krenelażu ${ }^{32}$, wówczas należałoby się zastanowić, czy otwory te nie są strzelnicami przystosowanymi do aktywnej obrony przy zastosowaniu broni palnej. Podobne innowacje, odnoszone do połowy bądź 2. połowy wieku XV znane są z kilku stanowisk małopolskich - Wawelu (Baszta Sandomierska; Pianowski 1991, s. 84-85), Lipowca (Holcerowa 1989, s. 29-31) i Pieskowej Skały (Lasek 2013, s. 161, fig. 3). Możliwe więc, że ojcowska wieża w 2. połowie XV wieku została

\footnotetext{
29 Jedyna, znana mi analogia dla motywu wyobrażonego na wspomnianym kaflu pochodzi z Wawelu (Firlet 1993, s. 108, tabl. XXVI). Zważywszy na niewielką odległość Ojcowa od ośrodka krakowskiego należy przypuszczać, że oba kafle są dziełem tego samego warsztatu.

${ }^{30}$ Oznaczenie monet zawdzięczam panu Mateuszowi Woźniakowi z Muzeum Narodowego w Krakowie, któremu składam w tym miejscu serdeczne podziękowania.

${ }^{31}$ Średniowieczne bruki stwierdzono natomiast na zamkowym majdanie (Wojenka 2016b). Można przypuszczać, że w najstarszej fazie funkcjonowania zamku poziom użytkowy wokół wieży stanowiło odpowiednio przygotowane, wyrównane podłoże skalne (ryc. 12).

32 Waldemar Niewalda i Halina Rojkowska podają informację o rozglifionych do wnętrza strzelnicach w budynku znajdującym się w południowej partii zamku. Dwie z nich położone są w odległości zaledwie około 1,5 m od siebie (Niewalda, Rojkowska 2001, s. 432, ryc. 7).
} 


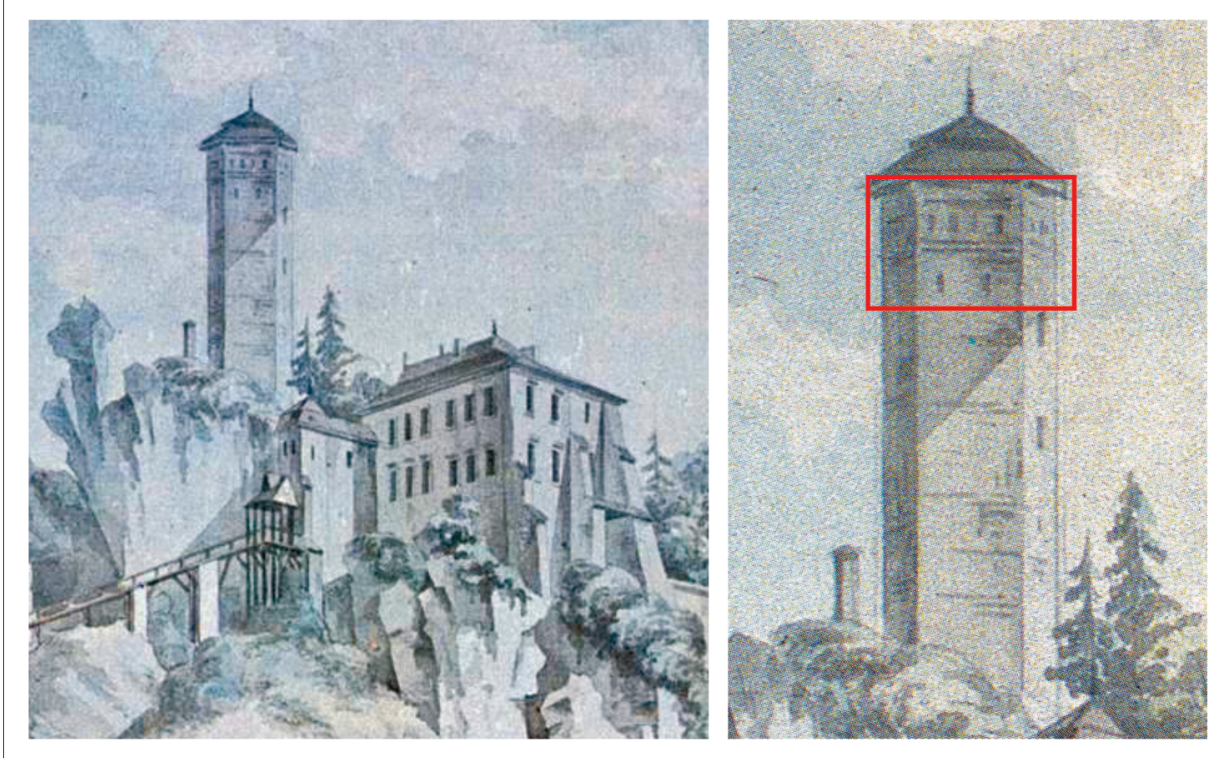

Ryc. 14. Zamek w Ojcowie. Wieża ośmioboczna na akwareli Zygmunta Vogla (1787 rok) Fig. 14. Castle in Ojców. Octagonal tower on Zygmunt Vogel's watercolor (1787)

gruntownie przebudowana lub nawet nadbudowana, co tłumaczyłoby obecność wokół niej wspomnianych warstw budowlanych.

\section{Zakończenie}

Pomimo przyrostu danych, który wynika z prac przeprowadzonych w ostatnich latach, wszystkie przedstawione w tekście założenia wymagają dalszych badań archeologicznych. Uwaga ta dotyczy w szczególności obiektów w Grodzisku koło Skały i w Ojcowie, choć szerzej zakrojonych prac winno doczekać się także założenie w Dubiu. Wypada również wrócić do warowni w Jerzmanowicach, gdzie na badania wykopaliskowe czekają przede wszystkim relikty fortyfikacji. W najbliższym czasie kontynuowane będą prace w Grodzisku koło Skały oraz na zamku w Ojcowie ${ }^{33}$.

\footnotetext{
${ }^{33}$ Przeprowadzone w latach 2015-2017 badania wykopaliskowe nie mogłyby dojść do skutku bez życzliwej pomocy wielu osób. Autor badań składa podziękowania duszpasterzowi parafii w Grodzisku, księdzu mgr. Stanisławowi Langnerowi za udostępnienie do badań terenu tzw. Pustelni błogosławionej Salomei w Grodzisku koło Skały oraz dr. inż. Henrykowi Pachli z firmy KROZ za nieocenioną pomoc przy zabezpieczeniu od strony technicznej prowadzonych tam prac. Dziękuję również konsultantom - dr Annie Bojęś-Białasik, dr. Dariuszowi Niemcowi, dr. Marcinowi Szymie i dr. Michałowi Wasilewskiemu. Winien jestem również słowa wdzięczności wszystkim Koleżankom i Kolegom, którzy zechcieli podzielić się ze mną swoją wiedzą o gotyckim detalu architektonicznym.
} 


\section{Bibliografia}

\section{Źródla}

Jan z Czarnkowa $\quad-$ Kronika Jana z Czarnkowa, tłumacz. J. Żerbiłło, oprac. tekstu i przypisów M. Kowalski, wyd. 3, Kraków 2001.

Kronika

- Kronika halicko-wolyńska. Kronika Romanowiczów, Kraków-Warszawa 2017.

KDM $\quad-$ Kodeks dyplomatyczny Małopolski, wyd. F. Piekosiński, t. 1: 1876; t. 3: 1887, Kraków.

\section{Literatura}

Adamczewski J.

1968 W starym Krakowie, Kraków.

Bereszyński Z.

2006 Jeszcze jedna warownia jurajska, Spotkania z Zabytkami, t. 30, nr 10, s. 20-21.

Bogdanowski J.

1993 Natura i kultura w krajobrazie Jury, t. 2: Sztuka obronna, Kraków.

Długopolski E.

2009 Władysław Łokietek na tle swoich czasów, wyd. 2, Kraków.

Domogalla W.

2005 Historia i przeobrażenia przestrzenne grodu, zamku i klasztoru ss. Klarysek w Grodzisku pod Skałą, maszynopis rozprawy doktorskiej w archiwum Politechniki Krakowskiej, Kraków.

2006 Zapinka w formie Manus Dei, [w:] Kraków w chrześcijańskiej Europie X-XIII w. Katalog wystawy, Kraków, s. 355-357.

Domogalla W., Mościcki W.

2006 Zastosowanie geofizycznych badań elektrooporowych w rozpoznaniu morfologii antropogenicznej na przykładzie zamku błogosławionej Salomei

Dreścik J. w Grodzisku pod Skała (Małopolska), Geologia, t. 32/4, s. 405-418.

1987 Kwiatki świętey pustynie B. Salomei panny, na Skale S. Maryey. Treści ideowe barokowej pustelni bł. Salomei w Grodzisku koło Skały, Folia Historiae Artium, t. 23, s. 37-83.

Falniowska-Gradowska A.

1995 Ojców w dziejach i legendzie, Ojców.

1999 Dzieje zamku ojcowskiego, Ojców. 
Najnowsze badania archeologiczne budownictwa obronnego...

Firlet J.

1993 Stratygrafia kulturowa na stanowisku Kraków-Wawel rejon VIII (międzymurze) w świetle badań wykopaliskowych, Acta Archaeologica Waweliana 1, Kraków.

Frazik J.

1966 Ruiny zamku w Ojcowie. Problemy badawcze i konserwatorskie, Czasopismo techniczne, R. 71, z. 4, s. 28-34.

Gąsiorowska P.

2015 Konwent klarysek krakowskich do końca XVIII wieku. Studium prozopograficzne, Kraków.

Grabowski A.

1822 Historyczny opis miasta Krakowa i iego okolic, Kraków.

Gradziński R.

1972 Przewodnik geologiczny po okolicach Krakowa, Warszawa.

Gradziński M., Gradziński R., Jach R.

2008 Geologia, rzeźba i zjawiska krasowe okolic Ojcowa, [w:] Monografia Ojcowskiego Parku Narodowego - Przyroda, red. A. Klasa, J. Partyka, Ojców, s. 31-95.

Gradziński R., Gradziński M., Michalik S.

$1994 \quad$ Natura i kultura w krajobrazie Jury, t. 3: Przyroda, Kraków.

Holcer Z.

2001 Zarys historii Grodziska koło Skały w średniowieczu (odkrycie trzeciego średniowiecznego murowanego zamku na terenie Ojcowskiego Parku Narodowego), [w:] Badania naukowe w poludniowej części Wyżyny Krakowsko-Częstochowskiej, red. J. Partyka, Ojców, s. 354-370.

Holcerowa T.

1989 Lipowiec - dawny zamek biskupów krakowskich, Warszawa.

2007 Barokowy zespól architektoniczno-przestrzenny tzw. Pustelni bł. Salomei w Grodzisku, powstały w 4. ćwierci XVII-początek XVIII w., Prądnik. Prace i Materiały Muzeum im. Prof. Władysława Szafera, t. 17, s. 167-194.

Jura Ojcowska w pradziejach

2006 Jura Ojcowska w pradziejach i w początkach państwa polskiego, red. J. Lech, J. Partyka, Ojców.

Kajzer L.

2013 Refleksje nad prawdziwym monumentem. Uwagi o lekturze dzieła Kazimierza Stronczyńskiego Opisy i widoki zabytków w Królestwie Polskim (1844-1855), Kwartalnik Historii Kultury Materialnej, R. 61, nr 1, s. 111-134.

Kętrzyński W.

1897 O rocznikach polskich, Rozprawy Wydziału historyczno-filozoficznego Akademii Umiejętności w Krakowie, t. 34, Kraków.

Kiryk F.

1978 Zarys dziejów osadnictwa, [w:] Dzieje Olkusza i regionu olkuskiego, t. 1, red. F. Kiryk, R. Kołodziejczyk, Warszawa-Kraków, s. 41-141. 
Kołodziejski S.

1985 Les éperons à molette du territoire de la Petite Pologne au Moyen Âge, [w:] Memoires Archeologiques, red. A. Kokowski, Lublin, s. 161-175.

1995 Zamek w Białym Kościele, Teki Krakowskie, t. 2, s. 89-100.

1996 Castrum Scala - zamek księcia ślaskiego Henryka Brodatego pod Krakowem, [w:] Kultura średniowiecznego Śląska i Czech. Zamek, red. K. Wachowski, Wrocław, s. 101-111.

1997 XIII-wieczne budowle warowne w dolinie Prądnika, Teki Krakowskie, t. 5, s. 71-80.

2006 Średniowieczne budowle obronne na terenie Jury Ojcowskiej w świetle wyników nowszych badań, Ojców.

2016 Budownictwo obronne, [w:] Monografia Ojcowskiego Parku Narodowego. Dziedzictwo kulturowe, red. J. Partyka, Ojców, s. 157-180.

Kondracki J.

1998 Geografia regionalna Polski, Warszawa.

Krakowski S.

1956 Polska w walce z najazdami tatarskimi w XIII wieku, Warszawa.

Kruczek K.

2001 Zamek w Ojcowie - wstępne wyniki badań wykopaliskowych prowadzonych w 1991 roku, [w:] Badania naukowe w południowej części Wyżyny Krakowsko-Częstochowskiej, red. J. Partyka, Ojców, s. 392-399.

Kurtyka J.

1997 Tęczyńscy. Studium z dziejów polskiej elity możnowładczej w średniowieczu, Kraków.

Kurzej M.

2014 Ksiądz Sebastian Piskorski a sztuka i historia, [w:] Sztuka po Trydencie, red. K. Kuczman, A. Witko, Kraków, s. 415-428.

Laberschek J.

1989 Grodzisko, [w:] Słownik historyczno-geograficzny województwa krakowskiego w średniowieczu, cz. 2, z. 1, Wrocław, s. 72.

1993 Zamek Ojców w średniowieczu, Aura, nr 3, s. 18.

1995 Osadnictwo średniowieczne w świetle źródel pisanych, [w:] Natura i kultura w krajobrazie Jury, t. 4: Pradzieje i średniowiecze, Kraków, s. 163-178.

1996 Pomnikowa monografia historyczna Ojcowa, Teki Krakowskie, t. 3, s. 269-273.

2000 Tajemnicze „castrum pesconis”. Próba rozwikłania zagadki rozbójniczego zamku małopolskiego z początku XIV stulecia, [w:] Krajobrazy. Księga pamiątkowa w 70. rocznice urodzin profesora Janusza Bogdanowskiego, red. S. Kołodziejski, J. Marcinek, R. Marcinek, Kraków, s. 143-148.

2016 Ojców i okolica do połowy XVI wieku, [w:] Monografia Ojcowskiego Parku Narodowego. Dziedzictwo kulturowe, red. J. Partyka, Ojców, s. 75-106. 
Najnowsze badania archeologiczne budownictwa obronnego...

Lasek P.

2013 Wieża i basteja. Z badań nad wpływem broni palnej na architekturę obronno-rezydencjonalna Królestwa Polskiego w XV-XVI w., [w:] Studia i Materiały Archeologiczne, Suplement 2: Interdyscyplinarne badania założeń rezydencjonalnych i obronnych, red. I. Iwanicka, M. Marciniak, Warszawa, s. 158-175.

Leńczyk G.

1938 Grodzisko w Piekarach, Kraków.

Medvedev A.

1966a Ručnoe metatel'noe oružie (luk i strely, samostrel) VIII-XIVvv., Arheologiâ SSSR. Svod arheologičeskih istočnikov, vyp. E1-36, Moskva.

1966b Tataro-mongol'skie nakonečniki strel v vostočnoj Evrope, Sovetskaâ Arheologiâ, nr 2(1966), s. 50-60.

Moskal K.

2012 Kafle w zbiorach Muzeum Historycznego Miasta Krakowa, Kraków.

Niewalda W., Rojkowska H.

2001 Badania ikonograficzne i architektoniczne zamku w Ojcowie w 1991 roku, [w:] Badania naukowe w południowej części Wyżyny Krakowsko-Często-

Olszacki T. chowskiej, red. J. Partyka, Ojców, s. 426-434.

2011 Rezydencje królewskie prowincji małopolskiej w XIV wieku-możliwości interpretacji, Czasopismo techniczne, R. 108, z. 23, s. 251-297.

2017 Ostatnie palatium? Królewski pałac $w$ Szydłowie $w$ świetle najnowszych badań, [w:] Gemma Gemmarum. Studia dedykowane Profesor Hannie Kóčce-Krenz, t. 2, red. A. Różański, Poznań, s. 955-993.

Pajor P.

2017 The poverty and the power. Duke Boleslaus the Chaste's Patronage of the Franciscans in 13th-century Lesser Poland, Umění 65/2, s. 106-122.

Pianowski Z.

1991 Wawel obronny, Kraków.

Radwański K.

1975 Kraków przedlokacyjny. Rozwój przestrzenny, Kraków.

Ratajczak T.

2014 Wieże mieszkalne na zamku wawelskim - badania nad chronologia gotyckiej architektury rezydencji królewskiej, Rocznik Historii Sztuki, t. 39, s. 177-190.

Rokosz M.

1995 Grodzisko skalskie nad Prądnikiem albo tzw. Pustelnia błogosławionej Salomei w XIII wieku, Prądnik. Prace i Materiały Muzeum im. Prof. Władysława Szafera, t. 10, s. 19-43.

Sikora F.

1986 Dubie, [w:] Słownik historyczno-geograficzny województwa krakowskiego w średniowieczu, cz. 1, z. 4, Wrocław, s. 619-625.

Stępień P.

2000/2001 Badania architektoniczne elewacji zamku na Wawelu, Studia Waweliana, t. 9/10, s. 129-191. 
Świętosławski W.

1997 Archeologiczne ślady najazdów tatarskich na Europe środkową w XIII w., Łódź.

Tutak J.

2001 Późnośredniowieczna ceramika z zamku w Białym Kościele nad Kluczwodą, maszynopis pracy magisterskiej w archiwum Instytutu Archeologii Uniwersytetu Jagiellońskiego, Kraków.

Uruszczak M.

2003 Czternastowieczne wieże strażnicze Jury Krakowsko-Częstochowskiej w świetle badań nad sztuką obronna w czasach Kazimierza Wielkiego, Czasopismo Prawno-Historyczne, t. 55, z. 2, s. 187-210.

Wałowy A.

1979 Późnośredniowieczne garncarstwo krakowskie w świetle źródel archeologicznych, Materiały Archeologiczne, t. 19, s. 5-151.

Wnęk K.

2013 Wielkie afery z mała monetą. Fałszowanie na wielka skale miedzianych szelagów Jana Kazimierza w drugiej połowie XVII wieku, Biuletyn Numizmatyczny, nr 3(371), s. 171-188.

Wojenka M.

2012 Jaskinie Wyżyny Krakowsko-Częstochowskiej w średniowieczu. Wstęp do problematyki, Prądnik. Prace i Materiały Muzeum im. Prof. Władysława Szafera, t. 22, s. 7-43.

2016a Jerzmanowice-Stara Wieś. Nowo odkryta warownia średniowieczna na Wyżynie Krakowsko-Częstochowskiej, [w:] Od Bachórza do Światowida ze Zbrucza. Tworzenie się słowiańskiej Europy w ujęciu źródłoznawczym. Księga jubileuszowa Profesora Michała Parczewskiego, red. B. Chudzińska, M. Wojenka, M. Wołoszyn, Kraków-Rzeszów, s. 663-673.

2016b Sprawozdanie z badań wykopaliskowych przeprowadzonych na zamku w Ojcowie w latach 2006-2014, Prądnik. Prace i Materiały Muzeum im. Prof. Władysława Szafera, t. 26, s. 199-224.

2018 Knights in the dark: on the function of Polish caves in the Middle Ages, [w:] Caves and ritual in Medieval Europe, AD 500-1500, red. M. Dowd, K. A. Bergsvik, Oxford-Philadelphia, s. 232-246.

Wróblewski K.

1907 Nad Pradnikiem. Przewodnik po Ojcowie i jego okolicy, Warszawa.

Zin W., Grabski W.

1970 Badania nad wczesnośredniowiecznym zespołem w Grodzisku k. Skały, Sprawozdania z Posiedzeń Komisji Naukowych PAN, t. XIII/1, s. 334-226.

Żaki A.

1974 Archeologia Małopolski wczesnośredniowiecznej, Wrocław. 


\title{
RECENT ARCHAEOLOGICAL RESEARCH ON DEFENSIVE ARCHITECTURE IN THE OJCÓW JURA
}

\author{
Keywords: Kraków-Częstochowa Upland, Ojców Jura, Middle Ages, castles, \\ strongholds, Grodzisko koło Skały, Jerzmanowice, Dubie, Ojców.
}

Summary

The article presents the results of excavations carried out in 2015-2017 on four defensive structures located in the area of the Ojców Jura (southern Poland). The first of the complexes is Grodzisko koło Skały, a place known primarily for late Baroque sacred construction, however its origins date back to the Middle Ages. According to some researchers, Grodzisko conceals the remains of the castle Scala of the Silesian Duke Henry the Bearded, mentioned in written sources from 1228 to the turn of the $13^{\text {th }}$ and the $14^{\text {th }}$ centuries. According to another, more widespread concept, this building housed a fortified St Clare's convent of the Duchess of Salomea, built under the privilege issued by Duke Bolesław the Chaste in 1257. The Poor Clares were to stay there until the beginning of the $14^{\text {th }}$ century, when the monastery was destroyed. Archaeological research concentrated in the central part of the complex, between the church wall and the so-called chaplain's house. The most important findings include the discovery of the destruction level of medieval buildings from the second half of the $13^{\text {th }}$ century or from the turn of the $13^{\text {th }}$ and the $14^{\text {th }}$ centuries, the determination of an artificial enlargement of the usable area of the complex by supplying large masses of soil and unearthing the walls of medieval cellars under the building of the chaplain's house.

In the newly discovered, located on the limestone outcrop, stronghold in Jerzmanowice, three small test trenches were dug. During the excavations, the remains of a wooden building with wattle construction of walls were found, which was destroyed by fire. Two arrowheads with steppe provenance, found in the destruction layer of the structure, indicate that the object could have been destroyed as a result of the invasion. It cannot be ruled out that it was the third Mongol invasion of Poland (1287/1288). The assemblage of pottery vessels from Jerzmanowice should be dated from the second half of the $13^{\text {th }}$ century to the beginning or the mid- $14^{\text {th }}$ century.

The works in Dubie consisted in cleaning the relics of the quadrilateral dwelling tower and digging a small test trench inside it. They did not bring about chronological findings, but they allowed to verify the previously published plan of the structure. The tower in Dubie must generally be dated to the late Middle Ages.

The research in Ojców castle was concentrated in the area of the octagonal tower, located in the highest part of the castle hill. This structure is considered one of the oldest elements of this royal fortress. During the works, a post-medieval wall was unearthed of the northern tower as well as relic of a building with stone foundations on its west side dated to the end of the Middle Ages or the early Post-medieval period. Many fragments of architectural details were also acquired: among other things. Gothic frames of windows and/or portals, perhaps from the earliest phase of the castle's use, which was built between 1354 and 1370. In the light of the above finds, it should be assumed that the tower originally had a dwelling function. 
